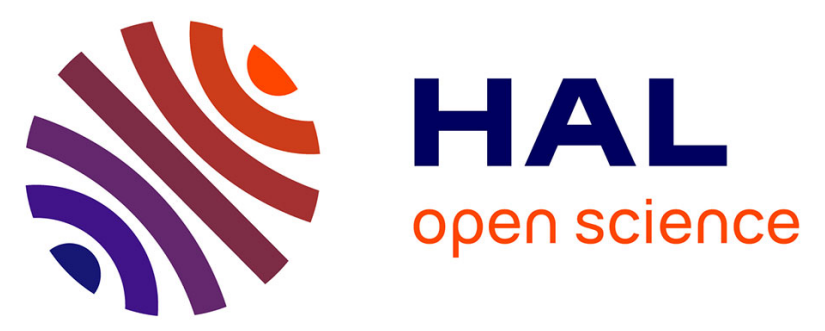

\title{
Late Devonian magmatism and clastic deposition in the upper Earn Group (central Yukon, Canada) mark the transition from passive to active margin along western Laurentia
}

Rose Cobbett, Maurice Colpron, James Crowley, Fabrice Cordey, Robert

Blodgett, Micheal Orchard

\section{To cite this version:}

Rose Cobbett, Maurice Colpron, James Crowley, Fabrice Cordey, Robert Blodgett, et al.. Late Devonian magmatism and clastic deposition in the upper Earn Group (central Yukon, Canada) mark the transition from passive to active margin along western Laurentia. Canadian journal of earth sciences, 2021, 58 (5), pp.471-494. 10.1139/cjes-2020-0161 . hal-03271657

\section{HAL Id: hal-03271657 https://hal.science/hal-03271657}

Submitted on 30 Jun 2021

HAL is a multi-disciplinary open access archive for the deposit and dissemination of scientific research documents, whether they are published or not. The documents may come from teaching and research institutions in France or abroad, or from public or private research centers.
L'archive ouverte pluridisciplinaire HAL, est destinée au dépôt et à la diffusion de documents scientifiques de niveau recherche, publiés ou non, émanant des établissements d'enseignement et de recherche français ou étrangers, des laboratoires publics ou privés. 
Late Devonian magmatism and clastic deposition in the upper Earn Group (central Yukon) mark the transition from passive to active margin along western Laurentia

Rose Cobbett, Yukon Geological Survey, PO Box 2703 (K14), Whitehorse, Yukon Y1A 2C6, Canada

Maurice Colpron, Yukon Geological Survey, PO Box 2703 (K14), Whitehorse, Yukon Y1A 2C6, Canada

James L. Crowley, Department of Geosciences, Boise State University, 1910 University Drive, Boise, Idaho, 83725-1535, USA

Fabrice Cordey, Université de Lyon, Université Claude Bernard Lyon 1, Laboratoire de Géologie de Lyon: Terre, Planètes, Environnement, LGLTPE, CNRS-UMR 5276, 69622 Villeurbanne, France

Robert B. Blodgett, Blodgett \& Associates LLC, 2821 Kingfisher Drive, Anchorage, Alaska 99502, USA

Micheal J. Orchard, Geological Survey of Canada, 605 Robson Street, 16th floor, Vancouver, BC, V6B 5J3, Canada

Corresponding author: Rose Cobbett, Rosie.Cobbett@gov.yk.ca, 867-455-2802 
Abstract

The Earn Group of central Yukon records the transition from a passive to an active margin along western Laurentia in the Late Devonian. Fine-grained clastic rocks and chert of the lower Earn Group contain late Early to Middle Devonian fossils and were deposited in an offshelf environment. The upper Earn Group comprises a mixture of sandstone and conglomerate, fine-grained siliciclastic rocks, and widespread crystal lithic tuff. Zircon from this succession are precisely dated using CA-IDTIMS methods on igneous (ca. $363 \mathrm{Ma}$ ) and detrital (ca. 378-363 Ma) grains and confirmed by Frasnian to Famennian fossils. Abrupt, along-strike facies changes within the upper Earn Group of the Glenlyon-Tay River area occur across mapped faults that are inferred to have originated as syndepositional extension faults in the Late Devonian. Occurrences of ca. 363 Ma tuff horizons within all facies of the upper Earn Group provide a temporal correlation across the area. Diorite plutons intrude lower Paleozoic rocks in the area and have U-Pb zircon crystallization dates of ca. $364 \mathrm{Ma}$. The diorite has calc-alkaline composition consistent with arc magmatism or crustal contamination. The Late Devonian magmatism in the Earn Group is coincident with onset of arc magmatism in the allochthonous Yukon-Tanana terrane, and extension related to rifting and opening of the Slide Mountain ocean in a back-arc setting. Magmatic rocks in the Earn Group of central Yukon thus represent part of a remnant continental arc and back-arc stranded behind the Slide Mountain ocean in the Mississippian.

Key Words: Late Devonian, magmatism, Earn Group, extension, western Laurentia, biostratigraphy 
Introduction

The western edge of North America (or Laurentia in the Paleozoic) was a passive continental margin from early Cambrian to Middle Devonian (Bond et al. 1983; Bond and Kominz 1984; Fritz et al. 1991; Kent 1994; Miall 2019). Passive margin deposition was interrupted in the Late Devonian. In the Rocky Mountains of eastern British Columbia and Alberta, shale and minor tuff of the Exshaw and Besa River formations replaced lower Paleozoic carbonate strata above a late Famennian regional unconformity (Richards et al. 1994, 2002). In Yukon, the development of a regional unconformity, coarse clastic sedimentation, and bimodal magmatism are inferred to reflect extension along the outer margin of Laurentia (Gordey et al. 1987; Gordey and Anderson 1993). In the western US, influx of westerly-derived coarse clastic rocks in the Late Devonian to Early Mississippian is interpreted as foreland deposits to a cryptic Antler orogen (e.g., Johnson and Pendergast 1981; Smith et al. 1993; Beranek et al. 2016). At that time, the northern Laurentian margin was also characterized by synorogenic deposition of a clastic wedge related to the Ellesmerian orogeny (Thorsteinsson and Tozer 1970; Trettin et al. 1991; Beranek et al. 2010; Lemieux et al. 2011; Lane 2007; Colpron and Nelson 2009). The Late Devonian tectonic instability along the western continental margin coincides with arc magmatism in peri-Laurentian terranes of the Cordillera (including the Yukon-Tanana terrane) and the establishment of a convergent margin along western Laurentia (Rubin et al. 1990; Mortensen 1992; Nelson et al. 2006; Colpron et al. 2007; Colpron and Nelson 2009). The onset of subduction was followed by back-arc rifting and opening of the Slide Mountain ocean in the Late Devonian to Mississippian (Creaser et al. 1999; Piercey et al. 2004; Colpron et al. 2007). As the nascent midPaleozoic arcs migrated away in front of the widening back-arc ocean, the Laurentian continental margin resumed its pattern of passive subsidence by Middle Mississippian (Gordey et al. 1991; Kent 1994; Richards et al. 1994, 2002; Miall 2019). In this model, Late Devonian to Early Mississippian magmatic rocks in outer continental margin strata are interpreted as segments of a remnant arc stranded behind the opening Slide Mountain ocean (Colpron and Nelson 2009). This is documented in ca. 360-354 Ma calc-alkaline magmatic rocks of the western Kootenay terrane in southern British Columbia (Eagle Bay assemblage; Paradis et al. 2006), and it has been inferred that coeval strata in the Earn Group of Yukon formed in a similar setting, but these rocks have not been studied in detail until now.

In this paper, we describe the sedimentary and igneous rocks of the Upper Devonian to Lower Mississippian Earn Group mapped in the Glenlyon-Tay River area of central Yukon (Fig. 1). In this region, volcanic rocks are widespread in the upper Earn Group and a series of Late Devonian diorite plutons intrude underlying lower Paleozoic rocks, but were poorly documented in previous studies (Campbell 1967; Gordey 2013a). We present new geochemical, biostratigraphic, and U-Pb zircon data for igneous and detrital samples that refine the stratigraphy of the Earn Group in central Yukon. These results show that strata of the upper Earn Group were deposited during extension of the margin and that Late Devonian calc-alkaline magmatism was coeval with, and likely related to, the onset of arc magmatism in the Yukon-Tanana and related terranes.

Regional Geology 
The North American Cordillera is an orogen that developed as a result of accretion of allochthonous terranes to the western margin of North America in the Mesozoic and Cenozoic (Monger and Price 2002; Nelson et al. 2013). The eastern part of the orogen comprises autochthonous and parautochthonous, mainly sedimentary shelf and slope facies that were deposited along the western Laurentian continental margin between late Neoproterozoic and early Mesozoic. To the west, the orogen is underlain by allochthonous terranes that represent parts of microcontinents, magmatic arcs, accretionary complexes and ocean basins (Nelson et al. 2013). The innermost, or Intermontane, allochthonous terranes comprise a series of magmatic arcs and associated accretionary complexes that were developed with some proximity to the western Laurentian margin (Colpron et al. 2007; Colpron and Nelson 2009). The oldest of these terranes, the Yukon-Tanana terrane (Late DevonianPermian), was founded on metasedimentary rocks that are inferred to represent a rifted fragment of western Laurentia (Piercey and Colpron 2009).

In Yukon, the division between allochthonous and parautochthonous rocks coincides for the most part with the Tintina fault, a Cenozoic dextral strike-slip fault with $\sim 430 \mathrm{~km}$ of displacement (Fig. 1; Gabrielse et al. 2006). Exceptions are segments of the Yukon-Tanana and Slide Mountain terranes in the Finlayson Lake area, northeast of the fault, and displaced continental margin rocks of the Cassiar terrane southwest of the fault. Lower Paleozoic continental margin strata comprise shallow-water carbonate and clastic rocks to the east and north (Mackenzie and Ogilvie platforms), and a western belt of deep-water, offshelf shale, chert, sandstone, and minor volcanic rocks were deposited in the Selwyn basin (Fig. 1; Gabrielse 1967; Gordey and Anderson 1993; Gordey 2013a). Deposition in Selwyn basin was interrupted in the Late Devonian, and older strata are unconformably overlain by the Upper Devonian to Lower Mississippian Earn Group, the subject of this study (Abbott 1986; Gordey et al. 1987; Gordey and Anderson 1993). Deposition of the Earn Group was locally controlled by syn-sedimentary extension faults and, along the northern edge of Selwyn basin, the entire lower Paleozoic succession was eroded and shed coarse clastic deposits to the south (Fig. 1, hatched region; Abbott et al. 1983; Gordey et al. 1987; Gordey and Anderson 1993). Deposition of shelf clastic and carbonate rocks resumed in the Carboniferous and persisted until the Triassic (Gordey 2013a).

The parautochthonous continental margin rocks of central Yukon were deformed into a northwesttrending fold-and-thrust belt following accretion of the allochthonous terranes to the west (Mair et al. 2006). The fold-and-thrust deformation postdates deposition of Upper Triassic (Norian) strata but predates intrusion of mid-Cretaceous (ca. 100-95 Ma) granitoid plutons (Gordey and Anderson 1993; Rasmussen 2013). From the Late Cretaceous to Paleocene, easterly propagation of the fold-andthrust belt continued in the Mackenzie Mountains to the east (e.g. Powell et al. 2016), but deformation in central Yukon was limited to localized faulting prior to development of the Tintina fault. Modern seismicity and GPS studies indicate that deformation persists at the mountain front today and that central Yukon is translated northeasterly at a rate of 2-5 mm/yr relative to the craton (e.g. Mazzotti and Hyndman 2002; Enkelmann et al. 2019).

Geology of the Glenlyon-Tay River area 
The study area straddles the Glenlyon (105L) and Tay River (105K) map areas (Fig. 2). Earlier mapping by Roddick and Green (1961, Tay River) and Campbell (1967, Glenlyon) first identified upper Paleozoic rocks in the region. Campbell $(1967$, p. 49) defined the Earn Group for upper Paleozoic sedimentary strata exposed near Earn Lake in eastern Glenlyon map area, and designated Crystal Peak as the type locality for two formations within the group: 1) conglomerate of the Crystal Peak Formation; and 2) limestone of the Lower Mississippian Kalzas Formation. Subsequent mapping in the Tay River area by Gordey (2013b) provided a structural framework for the area and first identifiethe major thrust sheets, including the Twopete and Stokes thrusts. Numerous fossil collections also helped refine the stratigraphic framework (Gordey 2013a). More recently, detailed mapping by Cobbett (2014, 2015, 2016a,b,c) and Cobbett and Keevil (2019) recognized that large parts of the Glenlyon-Tay River area previously assigned to the Cambrian-Ordovician Rabbitkettle Formation by Gordey (2013b) are actually underlain by strata of the Devonian Earn Group; a conclusion supported by fossils and U-Pb geochronological data presented here. The detailed mapping has also improved the structural framework of the area.

The south dipping Twopete and Stokes thrusts divide the area into three structural panels (Figs. 2 and 3). The geometry of the Twopete thrust varies from moderately-dipping in the southeast to shallow-dipping in the northwest (Figs. 2 and 3), a change that may reflect transition from a ramp to a flat geometry or folding of the thrust surface. Along the western edge of the map area, in the hanging wall of the Twopete thrust (the southernmost structural panel), the shallow-dipping section of the fault contains Silurian strata of the Road River Group intruded by porphyritic diorite plutons. East of Earn Lake, this structural panel is down-dropped by normal faults and occurs as a series of small klippe comprising strata of the Menzie Creek Formation, Road River and lower Earn Group groups, and porphyritic diorite plutons in the central part of the map area (Figs. 2 and 3). In the very southeast corner of the map, the hanging wall of the Twopete fault comprises the Menzie Creek Formation, Road River and Earn groups.

Cambrian to Silurian metasedimentary and metavolcanic rocks in the hanging wall of the Twopete thrust are equivalent to lower Paleozoic units described in the Anvil district to the south (Figs. 1 and 4; Jennings and Jilson 1986; Pigage 2004). The oldest rocks are well-foliated biotite-muscovite schist of the Cambrian Mount Mye formation (Figs. 2 and 4; informal unit of Jennings and Jilson 1986). It is unconformably overlain by the Cambrian-Ordovician Vangorda formation which comprises predominantly calc-silicate schist and amphibolite (Figs. 2 and 4; Jennings and Jilson 1986; Cobbett 2016a). The Vangorda formation is conformably overlain by volcanic rocks of the Ordovician-Silurian Menzie Creek Formation (Pigage 2004; Gordey 2013a; Cobbett 2016a). In the Glenlyon-Tay River area, the Menzie Creek Formation occupies the hanging wall of the Twopete thrust for much of its strike length (Figs. 2 and 3). Most exposures of the Menzie Creek Formation comprise thick piles of pillow basalt, vesicular and amygdaloidal basalt flows and bsalt breccia. 
In the Anvil district, the Road River Group gradationally overlies the Menzie Creek Formation (Pigage 2000). In the Glenlyon-Tay River area, the Menzie Creek Formation is thrust over the Road River Group along a splay of the Twopete thrust west of Earn Lake (Fig. 2). The Road River Group comprises siltstone, sandstone, and calcareous phyllite. East of Twopete Mountain, dark grey siltstone is assigned to the Road River Group based on plant stem fragments that are probably Silurian to Early Devonian. Strata of the Road River Group in the hanging wall and klippe of the Twopete thrust are intruded by a series of porphyritic diorite plutons that are further described below. In the southeast part of the area, a complete section from Road River Group to upper Earn Group is exposed in the hanging wall of the Twopete thrust (Figs. 2 and 4).

The lower two structural panels, in the footwall of the Twopete thrust to the north, are underlain primarily by un-metamorphosed Devonian to Triassic sedimentary rocks, including the Earn Group, and the Tay, Mount Christie and Jones Lake formations; this sequence is imbricated and repeated by the Stokes thrust (Figs. 2 and 3). Exposures of the Road River Group are limited to local imbrications along the Stokes thrust on the north slope of Crystal Peak.

In the Glenlyon-Tay River area, the Earn Group is divided into lower and upper successions (Fig. 4). The lower succession is exposed in the hanging wall of the Stokes thrust near Crystal Peak, within klippe of the Twopete thrust east of Earn Lake, and in the southeastern corner of the map area (Figs. 2, 3 and 5). It comprises fine-grained sandstone, siltstone and black chert. Strata of the Upper Devonian to Lower Mississippian upper Earn Group form the most extensive exposures in the footwall of the Twopete and Stokes thrusts (Figs. 2 and 3). These include quartz-rich clastic rocks, chert conglomerate, limestone, chert and tuff described in more detail below.

Carboniferous to Triassic strata of the Tay, Mount Christie and Jones Lake formations overlie the Earn Group and mainly occupy the immediate footwalls of the Twopete and Stokes thrusts (Figs. 2 and 3). In the southeast, the Tay Formation uncomformably overlies Emsian strata of the lower Earn Group and comprises medium-bedded silty limestone and siltstone that contain Tournaisian conodonts, corals, bivalves, ichthyoliths and conularids (Fig. 5a; Gordey 2013a). To the northwest, the Tay Formation is dominantly a thick bedded to massive, variably fossiliferous limestone that conformably overlies Upper Devonian strata of the upper Earn Group (the Kalzas Formation of Campbell 1967). In areas of sparse exposure, the Tay Formation is undifferentiated from the uppermost parts of the Earn Group (DMEua; Fig. 5b).

The Carboniferous to Permian Mount Christie Formation conformably overlies the Tay Formation (Figs. 2 and 5b; Gordey 2013a). It comprises thin-bedded chert that is most commonly green and maroon, but also grey, brown and black locally; siltstone interbeds are common. The youngest strata in the Glenlyon-Tay River area comprise a succession of cross-bedded sandy and silty limestone and siltstone of the Triassic Jones Lake Formation that unconformably overlie the Mount Christie Formation (Fig. 4; Gordey and Anderson 1993; Beranek et al. 2010; Gordey 2013a). 
Mid-Cretaceous granodiorite plutons of the Tay River suite (99-95 Ma; Mortensen et al. 2000; Colpron et al. 2016) cut the regional structures and locally impose contact metamorphism on the sedimentary successions. They are most voluminous along the southern part of the map area, where they form part of the Anvil batholith, and occur as a series of small plugs intruding the central structural panel (Fig. 2; Cobbett 2014, 2016a,b).

Upper Earn Group

The stratigraphy of the upper Earn Group varies along strike within the Stokes thrust sheet (Figs. 2 and 6). In the northwest, north of Earn Lake, the upper Earn Group on Crystal Peak comprises mainly chert-pebble conglomerate (Crystal Peak Formation of Campbell 1967) that grades upward into a coarse-grained sandstone and locally into a fine to medium-grained quartz arenite. Rare beds of fossiliferous, mildly calcareous, fine-grained sandstone crop out on Earn Mountain. Calcareous siltstone interbedded with lithic sandstone and coarse-grained fossiliferous sandstone are also minor constituents of the upper Earn Group in this area. Chert clasts in the conglomerate range from pebble to boulder size and are typically black, grey and brown in colour, with rare occurrences of turquoise chert pebbles. Medium-grained quartz-feldspar crystal tuff is present locally in one isolated exposure south of Crystal Peak (Figs. 2 and 6).

In the central part of the map area, between Earn Lake and Anvil Creek, the upper Earn Group comprises mainly fine-grained, quartz-rich clastic rocks (Fig. 6). These rocks are generally poorly exposed except near Twopete Mountain where they are largely altered to hornfels. As a result, the stratigraphy of the upper Earn Group is not known in detail but is distinct and termed the upper arenite unit (DMEua, Fig. 5b). This unit comprises quartzose siltstone, calcareous sandstone, bedded chert, thick bedded to massive quartz arenite, bedded limestone and locally, fossiliferous limestone, cross-bedded greywacke, chert pebble conglomerate and one horizon of crystal tuff (Fig. 6). Along Menzie Creek, a beige weathering welded tuff contains fiamme (Fig. 7a). On Twopete Mountain, chert occurs as a distinct unit within the upper arenite (DMEch; Fig. 6). On the north slope of Twopete Mountain, a distinct unit of grey weathering limestone debris flow interlayered with thinbedded limestone and calcareous sandstone occupies the core of a syncline over approximately 10 km (DMEud; Figs. 5b and 6) and represents the youngest strata in this area.

The upper Earn Group, south of Anvil Creek, is characterized by occurrences of two thick tuff horizons (Figs. 2, 5a and 6, southeast column). The base of the section is a grey-brown weathering, light grey, medium-grained quartz-feldspar-phyric crystal tuff (DMEuct; Figs. 5a and 6). The tuff is weakly foliated and composed of quartz shards and subhedral laths of plagioclase (altered to sericite) in a very fine-grained matrix of sericite and quartz (Fig. 8). Rare shale rip-up clasts occur near the basal contact of the tuff horizon. Lenses of chert pebble conglomerate and minor coarse-grained sandstone (DMEuc) up to thirty metres thick overlie the tuff. The conglomerate is in turn overlain by a distinct, orange-weathering siltstone thinly interbedded with fine-grained sandstone (DMEuss; Fig. 
6). This unit is characterized by soft sediment deformation features such as ball and pillow structures and flames. A second volcanic horizon overlies these fine-grained clastic rocks and comprises felsic tuff and amygdaloidal andesite (DMEut; Figs. 5a and 6). The tuff is a dark grey weathering, grey on fresh surfaces, medium to coarse-grained, crystal-lithic tuff composed of quartz shards and subhedral plagioclase crystals in a gritty matrix. It commonly contains shale chips that range in size from 0.5 to $15 \mathrm{~cm}$ (Fig. 7b). The andesite weathers beige, is light green and has abundant amygdules filled with calcite (Fig. 7c).

Late Devonian Intrusive Rocks

Three bodies of porphyritic diorite intrude the upper Menzie Creek Formation, and the Road River and lower Earn groups in the hanging wall of the Twopete thrust (Figs. 2 and 5b). The diorite forms prominent, steep-sided peaks in heavily treed areas (Fig. 9a). It comprises clinopyroxene \pm orthopyroxene \pm amphibole \pm plagioclase phenocrysts in a fine-grained matrix of equigranular plagioclase (Fig. 9b). The diorite varies from fine to medium-grained and from fresh to strongly altered (Fig. 10). South of Crystal Peak, amphibole phenocrysts in the diorite are pseudomorphed by chlorite (Fig. 10b, c), whereas east of Twopete Mountain pyroxene phenocrysts are relatively fresh (Fig. 10e, f). Stubby, square-shaped crystals of plagioclase comprise the groundmass in most samples of diorite and are a distinguishing feature of this unit (Fig. 10a, f).

Geochemistry

Seven samples of crystal-lithic tuff from the upper Earn Group and five samples of porphyritic diorite from the hanging wall of the Twopete thrust were analyzed for major and trace elements at Activation Laboratories in Ancaster, Ontario, and ALS Laboratories in Vancouver, BC (Table 1). Similar methodologies were employed at both laboratories (see Supplementary File 1 for details) and replicate analyses between laboratories show good correlations between them.

The interpretation of the geochemical data is primarily focused on immobile elements because these rocks are variably altered (Figs. 8 and 10). Although most samples have loss on ignition (LOI) values $<4 \%$ (Table 1), alteration is particularly evident in the tuff samples which have very low total alkali and high silica contents (70-80\% wt.\% SiO2; Fig. 11a). Shale chips and detrital components identified in the tuff suggest that these samples are not representative of primary igneous compositions; they are shown in Figure 11 for comparison with the diorite samples only. The diorite samples have silica contents of 60-68 wt.\% and total alkali of 3-7 wt.\% (Fig. 11a); this is consistent with diorite to granodiorite compositions (Middlemost 1994). On the immobile element classification diagram of Pearce (1996; modified after Winchester and Floyd, 1977), the diorite plot in sub-alkaline, intermediate composition fields (Fig. 11b). Comparatively, the upper Earn Group tuff plot near the diorite but have a slightly more alkaline signature (Fig. 11b). Diorite samples plot in the calc-alkaline field of the La-Yb diagram of Ross and Bédard (2009) and in the volcanic arc granite field of the Ta-Yb diagram (Fig. 11c,d; Pearce et al. 1984). The tuff samples also plot in the same fields as the diorite on the discrimination diagrams but show more scatter (Fig. 11b-d). 
Both the diorite and tuff samples have similar primitive mantle-normalized trace element patterns, with strong enrichment in light rare earth elements (LREE) and pronounced negative $\mathrm{Nb}$ and $\mathrm{Ti}$ anomalies (Fig. 12a). Two of the tuff samples have been removed from these plots based on petrographic analysis that showed them to have a higher abundance of detrital components and be affect by a higher degree of metamorphism. The remaining tuff samples have an overall slightly steeper slope than the diorite on the primitive mantle normalized multi-element plot indicated by the La/Yb ratios for the two groups (La/Ybtuff $=21-81$ and La/Ybdiorite $=7-14)$. On upper continental crust-normalized rare earth element plots, the diorite and tuff samples have distinct patterns. The diorite samples are very slightly depleted in the rare earth elements compared to upper continental crust and have flat profiles ( $\mathrm{La} / \mathrm{Sm}=0.8-1.0$ and $\mathrm{Ho} / \mathrm{Yb}=0.8-1.0$; Fig. 12b). Tuff from the upper Earn Group have slightly enriched but flat LREE profiles ( $\mathrm{La} / \mathrm{Sm}=1.1-1.2)$, and variably steep to flat negative slopes $(\mathrm{Ho} / \mathrm{Yb}=1.0-1.8)$ for the heavy rare earth elements (Fig. 12b).

Biostratigraphic constraints

Previous studies of the Earn Group in Yukon have reported macro- and microfossil collections that define an age range of Early Devonian to earliest Mississippian. Near the NWT boundary at Macmillian Pass (Fig. 1), conodont collections from the Portrait Lake Formation have ages ranging from late Pragian to early Tournaisian (Abbott 1983; Irwin and Orchard 1991). Barite horizons in the Earn Group between Macmillan Pass and Howard Pass yielded Givetian and Frasnian conodonts (Dawson and Orchard 1982), and an ammonoid found in scree above the Portrait Lake Formation is Frasnian (Gordey et al. 1982). In the Nahanni area near Howards Pass, graptolites and conodonts in the Portrait Lake Formation range from Pragian to middle Famennian, and conodont collections from the Prevost Formation have an overlapping range between Eifelian and Tournaisian (Gordey and Anderson 1993, p. 183). Overlying strata of the Tsichu Formation neat the NWT boundary yielded Early Mississippian conodonts and a probable Visean age providing a minimum constraint for strata of the Earn Group (Gordey and Anderson, 1993).

Gordey $(2013 a, b)$ mapped the Earn Group in the Tay River and Sheldon Lake map areas, east of our study area (Fig. 1); here, Lochkovian to Eifelian graptolites, conodonts and two-holed crinoids are observed in the Portrait Lake Formation. Conodonts and palynomorphs in the Prevost Formation indicate an early Famennian to late Tournaisian age, although the stratigraphic assignment of the younger conodont collection is uncertain (Gordey and Anderson 1993, their Fig. B-5). Conglomerate of the Crystal Peak Formation near Stokes Lake yielded two brachiopod collections that are middle Frasnian and possibly middle to late Tournaisian (Gordey 2013a, p. 137). The Tournaisian collection is reported as "too poorly preserved for definite age determination" and is comparable to fauna collected in the overlying Tay Formation in this region. The Tay Formation and its western equivalent in Glenlyon, the Kalzas Formation (Campbell 1967), are well-constrained as Mississippia(Tournaisian to Serpukhovian) by conodont and macrofossil faunas (Gordey 2013a; R.N. Cobbett, unpublished data) and provide minimum age constraints on the Earn Group in the area. 
We report new fossil collections from fourteen localities within the Glenlyon-Tay River area (Table 2; Figs. 2, 5, 6 and 13; S2). These fossils provide additional biostratigraphic constraints for sedimentary strata of the Earn Group in central Yukon. Collections that contain diagnostic fauna include radiolarians, conodonts, brachiopods, crinoids, trilobites and plant stems.

Lower Earn Group

Three macrofossil collections from thrust-imbricated strata in the southeastern part of the study area constrain the Early to Middle Devonian age of the lower Earn Group (Figs. 5a, 6; Table 2).

Strophomenoid and reticularid brachiopods collected from siltstone overlying black chert in a series of small gully exposures indicate a Pragian to Emsian age for strata in the lower thrust imbricate (15RC178; Table 2; Figs. 5a and 13a). Approximately $10 \mathrm{~m}$ up section in the same thrust imbricate, stringocephalid and productid brachiopods were recovered from cross-bedded sandy limestone interbedded with laminated, muddy siltstone that occur just below the unconformity at the base of the Tay Formation (13RC012; Fig. 5a; Table 2); this collection indicates an Emsian to Givetian age. In an overlying thrust imbricate approximately $6.3 \mathrm{~km}$ to the west, two-holed crinoid ossicles were observed in coarse-grained, fossiliferous sandstone interbedded within siliceous black siltstone, thus indicating an Emsian to Eifelian age for these strata (13RC030; Table 2; Fig. 5a).

Upper Earn Group

Ten new fossil collections constrain the Late Devonian age of the upper Earn Group in the GlenlyonTay River area (Table 2; S2). Macrofossils were recovered from three collections in coarse-grained lithologies in the northwest part of the area (Fig. 2). In the footwall of the Stokes thrust, weakly calcareous, quartz-rich, cross-bedded sandstone and lesser siltstone on the southern flank of Earn Mountain contain a single limestone bed (3-5 cm thick) that yielded Eleutherokomma sp. (Fig. 13b) and Cyrtospirifer sp. brachiopods that indicate a Frasnian age (16RC087; Table 2; Fig. 2).

Semi-continuous creek exposures in the immediate hanging wall of the Stokes thrust, between Crystal Peak and Earn Mountain, comprise shale, siltstone, calcareous siltstone, and calcareous, fossil-rich sandstone. Two samples yielded Schizophoria sp. (Fig. 13c) and Cyrtospirifer sp. brachiopods that indicate a Famennian age (16RC052, 16RC053; Table 2; Fig. 2). One collection (16RC052) also contains the brachiopod Athyris sp. which supports a Famennian age, together with indeterminate gastropod and bryozoan specimens.

The age of fine-grained rocks in the upper Earn Group from the central part of the Glenlyon-Tay River area is constrained primarily by new microfossil collections (Table 2; Figs. 2, 5b). An isolated exposure of laminated siltstone and fine-grained sandstone in the immediate footwall of the Twopete thrust, south of Earn Lake, contains $30 \mathrm{~cm}$-thick beds of calcareous, quartz-rich sandstone 
that yielded Icriodus sp. indet., Palmatolepis sp. indet., Polygnathus sp. indet. conodonts, indicating a Late Devonian, probably Frasnian age for these strata (16RC044; Table 2; Fig. 2). It is notable that conodonts in this collection consist entirely of fragments, which suggests possible transport and reworking of these elements (S2). To the east, near Mount Menzie (Fig. 5b), a fossiliferous limestone that has crinoids and yielded Apatognathus provarians, Bispathodus stabilis, Pelekysgnathus? sp. conodonts both indicate a late Famennian age (15RC162; Table 2). The structural interpretation for the central part of the Glenlyon-Tay River area (Fig. 3c) suggests that both these collections are from similar stratigraphic positions, although the sparse exposures in this region prclude precise correlation of strata across regional folds.

Approximately $7 \mathrm{~km}$ southwest of Twopete Mountain, the conodont Icriodus cf. iowaensis, recovered from calcareous sandstone interbedded with $1 \mathrm{~m}$ thick beds of quartz arenite and siltstone, indicate a Late Devonian age (13RC233; Table 2; Fig. 2). Approximately $1 \mathrm{~km}$ to the southeast, crinoidal silty limestone interbedded with dark grey siltstone yielded Polygnathus cf. P. spicatus conodonts giving a Tournaisian age (13RC230; Table 2; Fig. 2).

Black chert from two localities in the central part of the Glenlyon-Tay River area contain radiolarian taxa that support a Late Devonian to Mississippian age for the upper Earn Group. Southeast of Twopete Mountain, black and dark grey bedded chert contain Bientactinosphaera? sp., Palacantholithus? sp., and silica spheres that are consistent with a Late Devonian to Mississippian age (13RC100; Table 2; Fig. 5b). On Twopete Mountain, black chert that has distinct, discontinuous white-weathering lenses contains Entactiniids, Wonia? sp., and Spongothrochus? sp. radiolarians that indicate a Devonian to Carboniferous, possibly Mississippian age for these strata (13RC153; Table 2; Fig $5 \mathrm{~b}$ ). In the southeastern part of the Tay River area (Fig. 5a), a black chert bed in conglomerate of the upper Earn Group (DMEuc) yielded Entactiniids, Palacantholithus sp., Wonia sp. cf. concentrica, and Wonia sp. cf. turgida radiolarians that also indicate a Late Devonian to Carboniferous, possibly Mississippian age (13RC029; Table 2).

U-Pb geochronology

To further constrain the age of the upper Earn Group, eight samples of crystal lithic tuff and three of quartz-rich sandstone were dated by modern high-precision chemical abrasion isotope dilution thermal ionization mass spectrometry (CA-ID-TIMS) U-Pb zircon geochronology. Zircons from five samples of porphyritic diorite from the hanging wall of the Twopete thrust were also analyzed by U$\mathrm{Pb}$ methods. Samples were analyzed using a combination of laser ablation inductively coupled plasma mass spectrometry (LA-ICPMS) and CA-ID-TIMS methods at the Isotope Geology Laboratory at Boise State University (BSU; detailed methods and data are presented in Supplementary Files 3 and 4). Six of the tuff samples and one porphyritic diorite sample yielded prismatic zircons and were analyzed directly by CA-TIMS without imaging. Samples with a mixture of zircon morphologies were imaged by cathodoluminescence methods at BSU (CL; S5). Zircon from two tuff samples and four porphyritic diorite samples yielded large proportions of inherited zircons and were first analyzed by 
LA-ICPMS. Four of these samples (two tuff and two porphyritic diorite) contain a distinct young population of zircons that were subsequently analyzed by CA-TIMS. The three sandstone samples were analyzed using a combination of LA-ICPMS to determine detrital zircon populations followed by CA-TIMS analyses of select zircons from the youngest age peak to precisely establish the maximum depositional age of the rocks.

The results of $\mathrm{U}-\mathrm{Pb}$ analyses are summarized in Table 3 and described in Appendix 6 . Weighted mean $206 \mathrm{~Pb} / 238 \mathrm{U}$ dates were calculated from equivalent dates (probability of fit (pof) $>0.05$ ) at the young end of age spectra in the igneous samples using Isoplot 3.0 (Ludwig, 2003). These dates are interpreted as the ages of igneous crystallization (diorite) or eruption (tuff; Table 3). Reporting of errors for CA-TIMS dates are detailed in Table 3; only internal errors are given below for brevity.

Tuff samples

A single sample of quartz-feldspar crystal-lithic tuff was collected from the upper Earn Group in the northwest part of the Tay River area (Table 3; 18HK007). The small tuff outcrop occurs in the immediate footwall of the Twopete thrust, approximately $8 \mathrm{~km}$ west of the southern end of Earn Lake (Fig. 2). The sample yielded mostly Devonian-Mississippian zircons $(n=42)$ and a few older Precambrian inherited or detrital grains $(n=5)$; the weighted mean from three zircons is $362.96 \pm 0.07$ Ma (Fig. 14; Table 3).

Two crystal tuff samples were collected in the central part of the Glenlyon-Tay River area (Figs. 2 and 5a; Table 3). Sample 13RC280 is from undifferentiated strata of the upper Earn Group in the footwall of the Twopete thrust, approximately $7 \mathrm{~km}$ east of Anvil Lake (Fig. 2; Table 3). The quartz-feldspar crystal tuff is undeformed, but biotite porphyroblasts suggest that this area is affected by the contact aureole of the Anvil batholith (Fig. 8e). The weighted mean from three zircons is $363.32 \pm 0.15 \mathrm{Ma}$ (Fig. 14; Table 3). Sample 13RC111 is a thin horizon of crystal tuff from the upper arenite unit of the Earn Group (DMEua; Fig. 6), about 5 km southeast of Twopete Mountain (Fig. 5b). The weighted mean from five zircons is $363.26 \pm 0.11 \mathrm{Ma}$ (Fig. 14; Table 3).

Five tuff samples were collected south of Anvil Creek in the southeastern part of the Glenlyon-Tay River area (Figs. 2 and 5a). In this area, two separate tuff horizons are separated by several hundred metres of chert pebble conglomerate and finer-grained clastic rocks (Fig. 6). All samples selected for $\mathrm{U}-\mathrm{Pb}$ zircon geochronology are weakly foliated quartz-feldspar-phyric crystal tuff from the lower tuff horizon (unit DMEuct), the lowest part of the upper Earn Group in the area (Fig. 6). These samples are from isolated exposures and their relative positions within the unit are uncertain.

Three of the samples (13RC006, 13RC028, and 13RC129) were collected within $5 \mathrm{~km}$ north of the Twopete fault (Figs. 2 and 5a). The weighted mean from the youngest four of six zircons from sample 
$13 R C 006$ is $363.38 \pm 0.12 \mathrm{Ma}$; sample $13 R C 028$ is $363.24 \pm 0.11 \mathrm{Ma}(\mathrm{n}=5)$; and sample $13 R C 129$ is $363.47 \pm 0.10 \mathrm{Ma}$ ( $n=6$; Fig. 14; Table 3).

Sample $13 R C 112$ is from a quartz \pm chlorite \pm feldspar-phyric tuff horizon with a minimum thickness of one metre in undifferentiated upper Earn Group in the footwall of the Twopete thrust (Fig. 2; Table 3). The tuff has a well-developed foliation defined by flattened aggregates of chlorite and anastomosing bands of sericite \pm opaque minerals between quartz phenocrysts (Fig. 8f). The weighted mean from five of six zircons is $363.37 \pm 0.11 \mathrm{Ma}$ (Fig. 14; Table 3).

Sample 19RC276 is from the base of a $150 \mathrm{~m}$ thick section of crystal-lithic tuff that is well-exposed in the hanging wall of the Twopete thrust in the very southeast corner of the map area (Fig. 2). LAICPMS analyses revealed a mixture of Devonian-Mississippian igneous zircons $(n=28)$ and older Paleozoic and Precambrian inherited or detrital grains ( $n=19$; Table 3). The weighted mean from two of six young zircons is $363.44 \pm 0.09 \mathrm{Ma}$, which is interpreted as the eruption age (Fig. 14; Table 3).

Porphyritic diorite samples

Five samples of porphyritic diorite that intrude lower Paleozoic rocks in the hanging wall of the Twopete thrust were dated (Table 3). Two of these samples were collected in the northwestern part of our study area (Fig. 2). Sample 18RC081 is a medium-grained, pyroxene and plagioclase-phyric diorite (Fig. 10a) that crops out $\sim 13$ kilometres southwest of Crystal Peak (Fig. 2; Table 3). It has a mix of Paleozoic igneous zircon $(n=29)$ and Precambrian inherited zircon $(n=21)$. The weighted mean from four of the five younger zircons is $364.52 \pm 0.13 \mathrm{Ma}$ (Fig. 14; Table 3).

Sample 16RC061 was collected west of Earn Lake, where porphyritic diorite is exposed in several steep sided rocky knobs (Figs. 2 and 9a). The rock contains clinopyroxene and amphibole phenocrysts in a groundmass of plagioclase that is variably altered to sericite (Fig. 10b, c). The weighted mean from five of six zircons is $364.44 \pm 0.11 \mathrm{Ma}$ (Fig. 14; Table 3).

Three samples were collected within klippe of the Twopete thrust in the central part of the GlenlyonTay River area (Fig. 5b). Two rocks are from the large pluton northwest of Mount Menzie, which contains a historic U-Pb zircon (multi-grain fraction) date of $360 \pm 25 \mathrm{Ma}$ on a porphyritic diorite (Gordey and Mortensen, unpublished data in Yukon Geological Survey 2020a). Sample 15RC144 is a mildly altered pyroxene porphyritic diorite exposed on the north flank of Mount Menzie. Phenocrysts are completely altered to calcite and sericite with a groundmass of predominantly square plagioclase (Fig. 10d). Twenty-two zircons show distinct CL-dark cores and CL-bright rims, where LA-ICPMS analyses yielded Proterozoic $(n=12)$ and Devonian $(n=10)$ dates, respectively (Supplementary Files 4 and 5). The weighted mean from the nine youngest spots of $370 \pm 7 \mathrm{Ma}$ is interpreted as the crystallization age (Fig. 15; Table 3). 
Sample 16RC110 is a plagioclase-pyroxene-phyric diorite with euhedral, twinned plagioclase phenocrysts and subhedral pyroxene phenocrysts in a groundmass of dominantly fine-grained plagioclase (Fig. 10e, f). The rock is from one of several prominent rocky knobs located northwest of Mount Menzie (Fig. 5b). Seventeen grains analyzed by LA-ICPMS yielded mainly inherited Precambrian dates with only three Paleozoic dates. A weighted mean crystallization age of $362 \pm 12$ Ma is interpreted as the crystallization age (Fig. 15; Table 3).

Sample 13RC108 was collected $\sim 10 \mathrm{~km}$ east of Twopete Mountain (Fig. 5b), along the north slope of an east-west trending plateau. This pyroxene-phyric diorite has a fine-grained matrix comprised dominantly of plagioclase (Fig. 10g, h). LA-ICPMS analysis of 34 zircons shows a mix of Precambrian $(n=20)$ and Paleozoic dates ( $n=14$; Table 3). The weighted mean from three of four of the youngest zircons analyzed by CA-TIMS is $364.39 \pm 0.18 \mathrm{Ma}$ and is interpreted as the crystallization age (Fig. 14; Table 3).

Detrital zircon samples

Detrital zircon from three sandstones were analyzed, one from the northwest and two from the central parts of the Glenlyon-Tay River area (Fig. 2; Table 3). Sample 16RC085, collected from the footwall of the Stokes thrust on Earn Mountain, is a coarse-grained sandstone comprised mainly of sub-rounded chert grains, with lesser quartz and minor mudstone clasts. A total of 102 of 103 grains analyzed by LA-ICPMS yielded dates between 660-3393 Ma, with peaks in age probability at ca. 690, $730,1820,2710$ and $3120 \mathrm{Ma}$ (Fig. 16). Only one grain yielded a Paleozoic date of $385 \pm 13 \mathrm{Ma}$. This young grain was split into two fragments that were dated separately by CA-TIMS and yield a concordant weighted mean of $378.00 \pm 0.23 \mathrm{Ma}$ (Fig. 16; Table 3).

Sample 13RC107 is a medium-grained, quartz-rich, cross-bedded greywacke collected $10 \mathrm{~km}$ east of Twopete Mountain (Fig. 5b; Table 3), in a sequence of rocks that includes chert pebble conglomerate, typical of upper Earn Group stratigraphy (Fig. 6). A total of 78 of the 105 grains analyzed by LA-ICPMS yield dates of 961 to $2910 \mathrm{Ma}$, with peaks in age probability at ca. 1850 and $2700 \mathrm{Ma}$ (Fig. 16). The other 27 dates range from 334 to $413 \mathrm{Ma}$, with a peak at $357 \mathrm{Ma}$. Four zircon grains were dated by CA-TIMS, three of which yield dates of $364.23 \pm 0.25,364.81 \pm 0.26$ and $365.14 \pm 0.24 \mathrm{Ma}$. The fourth grain contains a much older inherited component (S3). The youngest date of $364.23 \pm 0.25 \mathrm{Ma}$ is considered the maximum depositional age (Fig. 16; Table 3).

Sample 13RC145 is a fine to medium-grained quartz arenite from an isolated exposure $2 \mathrm{~km}$ east of Twopete Mountain (Fig. 5b). In thin section, this sample comprises approximately $95 \%$ quartz, with polygonal quartz sub-grains developed around detrital quartz clasts. Nearby outcrops comprise hornfelsed, laminated siltstone similar to upper Earn Group from the southeast part of the Glenlyon- 
Tay River area (Fig. 5a). A total of 106 of the 109 grains analyzed by LA-ICPMS yield dates of 1683 to $2916 \mathrm{Ma}$, with peaks in age probability at ca. 1880, 2350, 2520 and $2700 \mathrm{Ma}$ (Fig. 16). Three grains have dates of 349 to $365 \mathrm{Ma}$, two of which yield CA-TIMS dates of $362.52 \pm 0.25$ and $363.11 \pm 0.25$ Ma. The youngest date of $362.52 \pm 0.25 \mathrm{Ma}$ is interpreted as the maximum depositional age (Fig. 16; Table 3).

Discussion

Age and facies variations in the Earn Group, Glenlyon-Tay River area

Detailed mapping of the Glenlyon-Tay River area provides new constraints on the stratigraphy of the Earn Group in central Yukon. Fossils collected for this study add to extensive collections from other parts of Yukon and are consistent with the late Early Devonian to earliest Mississippian age indicated for the Earn Group by previous studies (e.g., Abbott 1983; Irwin and Orchard 1991; Gordey and Anderson 1993; Gordey 2013a). Macrofossils recovered from limited exposures of the lower Earn Group in the study area indicate that this unit is restricted to the Early to Middle Devonian (late Pragian to Givetian; Figs. 6 and 17). Most of the exposures of the Earn Group in the Glenlyon-Tay River area belong to the upper Earn Group (Fig. 2) that contains mostly Late Devonian fauna (Frasnian-Famennian; Figs. 6 and 17). A single Tournaisian conodont collection from a limestone unit in the central part of the study area suggests the upper Earn Group may extend into the Early Mississippian. Alternatively, this limestone may represent an infold of the overlying Tay Formation within tightly folded strata in the footwall of the Twopete thrust (Fig. 2).

The upper Earn Group shows distinct facies associations in different parts of the study area. Within the Stokes thrust sheet, the upper Earn Group varies from conglomerate and coarse sandstone facies west of Earn Lake, to predominantly fine-grained siliciclastic rocks between Earn Lake and Anvil Creek, to a mixed clastic succession that contains thick accumulations of crystal lithic tuff southeast of Anvil Creek (Figs. 2 and 6). Although crystal lithic tuff is more prominent in southeastern exposures, thin horizons also occur in upper Earn Group strata of the central and northwestern part of the Stokes thrust sheet (Fig. 6). Uranium-lead zircon geochronology of eight samples of crystal tuff across the study area show that volcanism was restricted to $\leq 700 \mathrm{k} . y$. at ca. $363 \mathrm{Ma}$ and provides a tie between the various facies of the upper Earn Group in the Stokes thrust sheet (Figs. 6, 14 ad 17). The late Famennian age indicated by tuff horizons in the upper Earn Group is consistent with the maximum depositional ages determined from detrital zircons in two sandstone units collected below (364.23 $\pm 0.25 \mathrm{Ma} ; 13 \mathrm{RC107})$ and above (362.52 $\pm 0.25 \mathrm{Ma}$; $13 \mathrm{RC} 145)$ the tuff in the central part of the study area (Figs. 6, 16 and 17). A Famennian age is also indicated from most fossil collections from upper Earn Group strata in the central and northwestern parts of the Stokes thrust sheet. A single Frasnian conodont collection in the central part of the area west of Mount Menzie is inferred from structural interpretation to be from a stratigraphic horizon above the late Famennian tuff and sandstone with a ca. 364 Ma maximum depositional age, and thus appears to be anomalously old 
(Fig. 6). Considering that this collection consists entirely of broken conodont fragments, it is possible that it represents recycling of Frasnian conodont elements into younger strata of the upper Earn Group (Appendix 2). Older Earn Group strata were probably eroded from regions exposed at the favour of syn-sedimentary faults, as inferred for the area southeast of Anvil Creek (see below).

In the southeastern part of the study area, the late Famennian lower tuff horizon unconformably overlies late Middle Devonian black siliceous siltstone and shale of the lower Earn Group, and the Frasnian and lower Famennian portion of the upper Earn Group is missing (Fig. 6). To the northwest within the Stokes thrust sheet, there are more than $600 \mathrm{~m}$ of Famennian and older strata below the ca. $363 \mathrm{Ma}$ tuff horizon, and the upper Earn Group is conformable on underlying shale of the lower Earn Group on Crystal Peak (Fig. 6). The major changes in facies within the Stokes thrust sheet occur across the broad valleys of Anvil Creek and Earn Lake, where down-to-the-southeast normal faults are evident from offsets of map units and structures (Fig. 2). We infer that these Mesozoic structures may have antecedents in Late Devonian syn-sedimentary faults that were active during deposition of the upper Earn Group. Stratigraphic relationships suggest that the area south of Anvil Creek was a horst prior to deposition of the late Famennian tuff horizon, which ties all facies variations within the Stokes thrust sheet (Fig. 6). Part of the area probably remained emergent into the Mississippian as the Tay Formation unconformably overlies Lower Devonian strata of the Earn Group at lower structural levels (Fig. 5a)./span>

It is less certain whether the Earn Lake fault was active during deposition of the upper Earn Group and controlled the change from predominantly fine-grained siliciclastic rocks in the east to conglomerate and coarse sandstone in the west (Fig. 6). This change in facies could also reflect the edge of a submarine channel-levee complex as inferred by Gordey (2013a, p. 42) for conglomerates in the upper Earn Group, and the fault mapped at Earn Lake may have nucleated along this rheological facies boundary during Mesozoic deformation.

The succession of chert pebble conglomerate with minor chert-rich sandstone and quartz arenite northwest of Earn Lake was assigned to the Crystal Peak Formation by Campbell (1967; Early Mississippian or older?). Strata in the footwall of the Stokes thrust, near Earn Mountain and Stokes Lake, are similar to the Crystal Peak section and were also assigned to this formation (Campbell 1967; Gordey 2013a). Brachiopod fauna on Earn Mountain (16RC087, Appendix 2) and east of Stokes Lake (GSC \#42482, Gordey 2013a, p. 137) contain the genera Eleutherokomma sp. and Cyrtospirifer sp., which indicate a middle Frasnian age for these strata. The maximum depositional age of ca. $378 \mathrm{Ma}$ from detrital zircons in sample 16RC085 (Fig. 16) is consistent with the brachiopod fauna (Fig. 17; Cohen et al. 2013). Another collection of poorly preserved brachiopods east of Stokes Lake (GSC \# C150017) was interpreted by Gordey (2013a) to indicate a Tournaisian age for the Crystal Peak Formation, but our data are more consistent with a Late Devonian age for the conglomerate based on more precise age determinations on Earn Mountain and in the hanging wall of the Stokes thrust. 
The subdivision between lower and upper Earn Group in the Glenlyon-Tay River area is broadly equivalent with the Portrait Lake and Prevost formations mapped by Gordey $(2013 a, b)$ in the adjacent Sheldon Lake-Tay River area to the east (Fig. 4). The Portrait Lake Formation is characterized by generally fine-grained lithology, including chert and shale, whereas the Prevost Formation comprises coarse-grained sandstone and local conglomerate interbedded with shale and siltstone. The Early to Middle Devonian age and fine-grained lithology of the lower Earn Group in our study area are consistent with the Lochkovian-Eifelian age of the Portrait Lake Formation to the east (Gordey 2013a, b). The limited Famennian-Tournaisian conodont collections from the Prevost Formation in the Sheldon Lake-Tay River area are also consistent with the age of the upper Earn Group in our study (Fig. 17). However, farther east near the NWT boundary, fossil collections indicate that the Portrait Lake Formation spans the entire Devonian and locally overlaps with the range of conodonts recovered from strata of the Prevost Formation (Fig. 17; Abbott 1983; Irwin and Orchard 1991; Gordey and Anderson 1993). These relationships indicate that at the regional scale formations in the Earn Group, as defined by their lithologic characteristics (Gordey and Anderson 1993), represent in part lateral facies variations rather than simple stratigraphic superposition. Our study of Earn Group strata within the Stokes thrust sheet in the Glenlyon-Tay River area provides a clear example of abrupt facies variations within Upper Devonian strata of the upper Earn Group (Fig. 6).

Detrital zircon analyses from three sandstones in the upper Earn Group yielded similar age populations with predominantly Paleoproterozoic and Archean grains and peaks at ca. 1.9-1.8 Ga and ca. $2.7 \mathrm{Ga}$ (Fig. 16). Minor Mesoproterozoic zircons are present in two samples and one sample (16RC085) contains 15\% Neoproterozoic grains (760-660 Ma; Fig. 16; S5). Devonian zircons are present in all three samples, but only represent a significant population ( 25\%) in sample 13RC107.

In general, the pattern of Precambrian zircons matches the signature of lower Paleozoic continental margin strata from northern British Columbia and points to ultimate sources in the northwestern Laurentian craton (Gehrels et al. 1995; Gehrels and Pecha 2014). The population of Neoproterozoic zircons in sample 16RC085 is less common, although it is locally reported in Cambrian sandstones from southeastern Yukon (Pigage et al. 2015; D. Moynihan, pers. comm., 2019). Potential 'local' sources for these zircons can be found in volcanic rocks of the Mount Harper Group in west-central Yukon (718-716 Ma; Macdonald et al. 2018) and the Gataga volcanics of northeastern British Columbia (696-690 Ma; Fig. 1; Eyster et al. 2018).

The pattern of Precambrian zircons in sandstone of the upper Earn Group suggests either direct derivation from sources in the northwestern Laurentian craton (Great Bear/Wopmay and Slave provinces; e.g., Gehrels and Pecha 2014) or recycling of older continental margin strata. Recycling of older strata is indicated by occurrence of laterally discontinuous chert pebble conglomerate and chert-quartz arenite in the upper Earn Group (e.g. Crystal Peak Formation of Campbell 1967; Gordey 2013a). These are interpreted as submarine fan and channel deposits that developed in an extensional setting in the Late Devonian (Gordey et al. 1987). The chert and quartz clasts in the coarse-grained rocks are inferred to be derived from strata of the Ordovician-Devonian Road River 
Group and Ediacaran-Cambrian Hyland Group, respectively (Gordey and Anderson 1993; Gordey 2013a). At the regional scale, Upper Devonian strata of the Earn Group unconformably overlie progressively older sedimentary rocks to the northwest, with Earn Group sitting directly on strata of the Hyland Group at the northern edge of Selwyn basin (Yukon Geological Survey 2020b), and this region is the inferred source for coarse clastic deposits in the Earn Group (Fig. 1; Gordey et al. 1987; Gordey 2013a).

Magmatism and tectonics of western Laurentia in the Late Devonian

Porphyritic diorite that intrudes lower Paleozoic rocks in the hanging wall of the Twopete thrust yield Late Devonian U-Pb zircon dates that are consistently $\sim 1$ m.y. older than dates from tuffs in the Stokes thrust sheet below (Figs. 14, 15 and 17). Although both diorite and tuff have the general character of calc-alkaline, continental arc rocks, stronger enrichment in $\mathrm{SiO} 2, \mathrm{Th}, \mathrm{Zr}$, $\mathrm{Nb}$ and LREE may indicate more crustal influence or mixing with detrital components in the tuff (Figs. 11 and 12). Mixing with crustal or sedimentary sources is evident in occurrence of older, inherited zircon components in some tuff and diorite samples (Table 3; S5). The difference in age and geochemistry suggest that diorite and tuff result from distinct Devonian magmatic events.

The Late Devonian tuff and diorite exposed in the Glenlyon-Tay River area represent some of the most extensive exposures of magmatic rocks in the Earn Group in Yukon. Mafic to intermediate volcanic rocks were mapped by Abbott (2013) near Macmillan Pass in eastern Yukon (Fig. 1). There the volcanic rocks are constrained as Givetian to early Frasnian by conodonts in enclosing strata (Fig. 17; Abbott 1983, 2013); they represent a distinct, older Middle Devonian magmatic event compared to Late Devonian magmatism in our study area. Felsic volcanic rocks in the Earn Group are also documented in association with the Marg volcanogenic massive sulphide deposit, 130 km north of the Glenlyon-Tay River area (Fig. 1; Abbott 1990; Gordey 1990; Roots 1997). Crystal tuff horizons in this area yielded U-Pb zircon dates between 381 and $378 \mathrm{Ma}$ (Roots 1997; M. Colpron, unpublished data in Yukon Geological Survey 2020a). Although felsic rocks near Marg have similar calc-alkaline compositions as porphyritic diorites in the Glenlyon-Tay River area (Fig. 11), magmatism at Marg is more than 10 m.y. older and clearly represent a distinct, early pulse of calc-alkaline magmatism in the Earn Group (Fig. 17). It should be noted that the youngest detrital zircon in a sandstone from Earn Mountain, in the footwall of the Stokes thrust, is ca. $378 \mathrm{Ma}$ (Fig. 16) and that the Marg area coincides with the inferred source region for Upper Devonian coarse clastic rocks of the upper Earn Group (Fig. 1; Gordey et al. 1987; Gordey 2013a). Late Devonian magmatism is also documented in displaced continental margin rocks southwest of the Tintina fault. In central Yukon, a ca. $363 \mathrm{Ma}$ syenite pluton intrudes mafic to intermediate volcanic rocks associated with black shale and chert sandstone correlated with the Earn Group on Cassiar terrane (Fig. 1; Seagull Group of TempelmanKluit 2012; Beranek et al. 2016). Although coeval with the 364-363 Ma magmatism in the GlenlyonTay River area, the alkalic composition of volcanic rocks in the Seagull Group is distinct from that of 
felsic, calc-alkaline rocks of the Earn Group northeast of the Tintina fault. It should also be noted that prior to Cenozoic displacement on the Tintina fault, rocks of the Seagull Group restore more than 430 $\mathrm{km}$ south of their current location.

Felsic metavolcanic rocks of the Salcha River area (Butte assemblage) in east-central Alaska are hosted in carbonaceous metasedimentary rocks (Blackshell unit) that are inferred to represent part of a metamorphosed, parautochthonous continental margin succession correlative with parts of Selwyn basin and the Earn Group of Yukon (Fig. 1; Dusel-Bacon et al. 2004, 2006). Rocks of the Butte assemblage range from ca. 371 to $364 \mathrm{Ma}$, but as with rocks of the Seagull Group on Cassiar terrane, their alkalic composition precludes direct correlation with Late Devonian magmatic rocks of the Glenlyon-Tay River area.

The Late Devonian magmatism in the Earn Group of central Yukon coincides with onset of arc magmatism in the allochthonous Yukon-Tanana terrane (Fig. 17; Mortensen 1992; Piercey et al. 2006; Nelson et al. 2006). The Yukon-Tanana terrane consists of a series of nested arc sequences of Late Devonian to early Permian age that were built in part on a metasedimentary succession of continental margin affinity (Colpron et al. 2006; Piercey and Colpron 2009). Magmatism began at ca. $365 \mathrm{Ma}$ in the back-arc region (Finlayson Lake district; Fig. 1; Murphy et al. 2006; Manor et al. 2019) and extensive arc magmatism was established across the terrane by ca. 355-345 Ma (Piercey et al. 2006). Onset of arc magmatism was accompanied by rifting in the back-arc region and opening of the Slide Mountain oean in the Mississippian (Mortensen 1992; Creaser et al. 1999; Nelson et al. 2006; Colpron et al. 2007). The syn-sedimentary extensional faults and magmatism in Late Devonian strata of the Earn Group in central Yukon (Gordey et al. 1987; Gordey 2013a; this study) are coeval with rifting of Slide Mountain and onset of arc magmatism in the Yukon-Tanana terrane, suggesting that they formed part of the same geodynamic environment in the Late Devonian. Alkalic magmatism on Cassiar terrane (Seagull Group) and in east-central Alaska (Salcha River) probably relate to Late Devonian rifting. Felsic, calc-alkaline magmatism in the Earn Group of central Yukon (Marg deposit and Glenlyon-Tay River area) may form part of a remnant arc stranded behind the Slide Mountain ocean in the Mississippian, or reflect crustal contamination of back-arc rift rocks. A remnant arc succession is suggested for part of the Kootenay terrane in southern British Columbia where magmatism east of the Slide Mountain terrane is ca. 367-354 Ma (Fig. 1; Paradis et al. 2006; Kraft 2013).

The Late Devonian period of tectonic instability is also recorded in platformal rocks of the southeastern Canadian Cordillera where shale of the Upper Devonian to Lower Mississippian Exshaw Formation mark a hiatus in carbonate deposition and contain ca. 363-359 Ma tuff horizons (Fig. 1; Richards et al. 2002; Ekhoff et al. 2013). By the late Tournaisian-Viséan (middle Mississippian) western Laurentia returned to normal continental margin deposition (e.g. Tay Formation in this study) controlled by post-rift thermal subsidence following opening of the Slide Mountain ocean (Richards et al. 2002; Gordey 2013a; Miall 2019). 
Conclusions

1) Strata of the Earn Group in the Glenlyon-Tay River area of central Yukon comprise a lower unit dominated by siltstone, shale and chert with late Early to Middle Devonian (late Pragian to Givetian) fossils (Lower Earn on Figure 4), and an upper unit that includes a mixture of coarse-grained sandstone, conglomerate, siltstone, shale, chert, and widespread and locally thick successions of crystal lithic tuff (Upper Earn on Figure 4.).

2) Fossil collections from the upper Earn Group indicate a Frasnian to Famennian (Late Devonian) age for this unit, which overlap with precise U-Pb zircon dates for tuff samples that show all tuff occurrences were deposited within $\leq 700$ k.y. at ca. 363 Ma.

3) Detrital zircon analyses from sandstones in the upper Earn Group further constrain its Late Devonian age and are consistent with 'local' sources in northwestern Laurentia.

4) Abrupt, along-strike facies changes in the upper Earn Group occur across a series of faults with inferred origins as syn-sedimentary extension faults in the Late Devonian. South of Anvil Creek, Frasnian to lower Famennian strata are missing beneath the upper Famennian tuff, suggesting this block was uplifted in the Late Devonian possibly as a fault-bound horst. The Earn Lake fault to the northwest may have been a Late Devonian syn-sedimentary fault as well or could also have nucleated in the Mesozoic at the edge of a submarine channel-levee complex.

5) Crystal lithic tuff (ca. $363 \mathrm{Ma}$ ) occur in all facies associations of the upper Earn Group across the area and provide a stratigraphic correlation for the various sections across the inferred syndepositional faults.

6) Porphyritic diorite that intrude lower Paleozoic rocks in the hanging wall of the Twopete thrust are dated by U-Pb zircon at ca. $364 \mathrm{Ma}$ and are distinctly older that the tuff to the north.

7) The diorite has calc-alkaline composition and trace element patterns that may be related to a continental arc setting or reflect crustal contamination of the magma.

8) Late Devonian magmatism in the Earn Group is coeval with onset of arc magmatism in the allochthonous Yukon-Tanana terrane, and syn-depositional extension of the western Laurentian 
margin reflects rifting and opening of the Slide Mountain ocean in Late Devonian to Early Mississippian.

9) The Late Devonian magmatic rocks in the upper Earn Group thus represent part of a remnant arc and back-arc, similar to the western Kootenay terrane of southern British Columbia, that were stranded behind (craton-ward of) the Slide Mountain ocean in the Mississippian.

Acknowledgements

Kane Keating, Melissa Friend, Reid van Drecht, Alex Brubacher, Ryan Burke and Heather Clarke provided excellent field assistance. Halley Keevil assisted in mapping parts of the study area. Comments by David Moynihan and discussions with Don Murphy provided guidance early in the process of writing this manuscript. Review of an early version of the manuscript by Matt Manor has improved its clarity. Detailed and constructive reviews by Alex Zagorevski and an anonymous reviewer helped fine-tuned the paper. This is Yukon Geological Survey contribution \#47.

References

Abbott, J.G. 1983. Structure and stratigraphy of the MacMillan fold belt: evidence for Devonian faulting. Department of Indian Affairs and Northern Development, Geology Section, Open File 1983$1,16 \mathrm{p}$.

Abbott, J.G. 1990. Geological map of Mt. Westman map area (106D/1). Yukon Geological Survey, Open File 1990-1, scale 1:50,000.

Abbott, J.G., 2013. Bedrock geology of the MacMillan Pass area, Yukon and adjacent Northwest Territories. Yukon Geological Survey, Geoscience Map 2013-1, scale 1:50,000.

Abbott, J.G. 1986. Setting of sediment-hosted stratiform lead-zinc deposits in Yukon and northeastern British Columbia. Mineral Deposits of the Northern Cordillera. Canadian Inst. Mining Metal., 37: 1-18. 
Barrett, T. J. and MacLean, W. H. 1999. Volcanic sequences, lithogeochemistry, and hydrothermal alteration in some bimodal volcanic-associated massive sulfide systems. Reviews in Economic Geology, 8: 101-131.

Beranek, L. P., Piercey, S. J., Campbell, R. and Wawrzonkowski, P. 2016. Paleozoic stratigraphy, tectonics and metallogeny of the Pelly Mountains, Quiet Lake and Finlayson Lake map areas (NTS $105 \mathrm{~F}$ and G), central Yukon: Project outline and preliminary field results. In Yukon Exploration and Geology 2015. Edited by MacFarlane, K. E. and M. G. Nordling. Yukon Geological Survey, pp. 17-28.

Beranek, L. P., Link, P. K. and Fanning, C. M. 2016. Detrital zircon record of mid-Paleozoic convergent margin activity in the northern U.S. Rocky Mountains: Implications for the Antler orogeny and early evolution of the North American Cordillera. Lithosphere, 8: 533-550.

Beranek, L. P., Mortensen, J. K., Lane, L. S., Allen, T. L., Fraser, T. A., Hadlari, T. and Zantvoort, W. G. 2010. Detrital zircon geochronology of the western Ellesmerian clastic wedge, northwestern Canada: Insights on Arctic tectonics and the evolution of the northern Cordilleran miogeocline. Geological Society of America Bulletin, 122: 1899-1911.

Beranek, L. P., Mortensen, J. K., Orchard, M. J. and Ullrich, T. 2010. Provenance of North American Triassic strata from west-central and southeastern Yukon: correlations with coeval strata in the Western Canada Sedimentary Basin and Canadian Arctic Islands. Canadian Journal of Earth Sciences, 47: 53-73.

Bond, G. C. and Kominz, M. A. 1984. Construction of tectonic subsidence curves for the early Paleozoic miogeocline, southern Canadian Rocky Mountains: Implications for subsidence mechanisms, age of breakup and crustal thinning. Geological Society of America Bulletin, 95: 155173.

Bond, G. C., Kominz, M. A. and Devlin, W. J. 1983. Thermal subsidence and eustasy in the lower Paleozoic miogeocline of western North America. Nature, 306: 775-779.

Campbell, R. B. 1967. Geology of Glenlyon map-area, Yukon Territory (105 L). Geological Survey of Canada, Memoir 352, 92 p. 
Cobbett, R. N. 2014. Preliminary observations on the geology of the Anvil Lake area (parts of NTS $105 \mathrm{~K} / 11$ and 12), central Yukon. In Yukon Exploration and Geology 2013. Edited by K.E. MacFarlane, M.G. Nordling and P.J. Sack. Yukon Geological Survey, pp. 33-51.

Cobbett, R. 2015. Geological map of the Anvil Lake area, central Yukon, parts of NTS $105 \mathrm{~K} / 11$ and 105K/12. Yukon Geological Survey, Open File 2015-2, scale 1:50,000.

Cobbett, R. N. 2016a. Preliminary observations on the geology of the Tay Mountain area (parts of NTS 105K/12 and 13, 105L/09 and 16), central Yukon. In Yukon Exploration and Geology 2015. Edited by K.E. MacFarlane and M.G. Nordling. Yukon Geological Survey, pp. 79-98.

Cobbett, R. 2016b. Geological map of the Tay Mountain area, central Yukon, parts of NTS 105K/12, 105K/13, 105L/09 and 105L/16. Yukon Geological Survey, Open File 2016-3, scale 1:50,000.

Cobbett, R. N., 2016c. Geological map of the Earn Lake area, central Yukon, parts of NTS 105L/9, 105L/15, and 105L/16. Yukon Geological Survey, Open File 2016-40, scale 1:50,000.

Cobbett, R. and Keevil, H. 2019. Geology of northeast Glenlyon area (NTS 105L/10, 13, 14, 15). Yukon Geological Survey, Open File 2019-3, scale 1:50,000.

Cohen, K.M., Finney, S.C., Gibbard, P.L., and Fan, J. 2013. (updated 2019). The International Chronostratigraphic Chart. Episodes 36: 199-204.

Colpron, M. and Nelson, J. L. 2009. A Paleozoic Northwest passage: Incursion of Caledonian, Baltican and Siberian terranes into eastern Panthalassa, and the early evolution of the North American Cordillera. In Accretionary orogens through time. Edited by Cawood, P. and A. Kröner. Geological Society of London, Special Publications 318, pp. 273-307.

Colpron, M. and Nelson, J. L. 2011. A digital atlas of terranes for the northern Cordillera. Yukon Geological Survey, http://data.geology.gov.yk.ca/Compilation/2, accessed: March 30, 2019.

Colpron, M., Israel, S. and Friend, M. 2016. Yukon plutonic suites. Yukon Geological Survey, Open File 2016-37, scale 1:750,000. 
Colpron, M., Nelson, J. L. and Murphy, D. C. 2006. A tectonostratigraphic framework for the pericratonic terranes of the northern Cordillera. In Paleozoic Evolution and Metallogeny of Pericratonic Terranes at the Ancient Pacific Margin of North America, Canadian and Alaskan Cordillera. Edited by Colpron, M. and J. L. Nelson. Geological Association of Canada, Special Paper 45, pp. 1-23.

Colpron, M., Nelson, J. L. and Murphy, D. C. 2007. Northern Cordilleran terranes and their interactions through time. GSA Today, 17, no. 4/5: 4-10.

Creaser, R. A., Goodwin-Bell, J. S. and Erdmer, P. 1999. Geochemical and Nd isotopic constraints for the origin of eclogite protoliths, northern Cordillera: implications for the Paleozoic tectonic evolution of the Yukon-Tanana terrane. Canadian Journal of Earth Sciences, 36: 1697-1709.

Dawson, K.M. and Orchard, M.J. 1982. Regional metallogeny of the northern Cordillera: biostratigraphy, correlation and metallogenic significance of bedded barite occurrences in eastern Yukon and western District of Mackenzie. In Current Research, Part C. Geological Survey of Canada, Paper 82-1: 31-38.

Dusel-Bacon, C., Wooden, J. L. and Hopkins, M. J. 2004. U-Pb zircon and geochemical evidence for bimodal mid-Paleozoic magmatism and syngenetic base-metal mineralization in the Yukon-Tanana terrane, Alaska. Geological Society of America Bulletin, 116: 989-1015.

Dusel-Bacon, C., Hopkins, M.J., Mortensen, J.K., Dashevsky, S.S., Bressler, J.R. and Day, W.C. 2006. Paleozoic tectonic and metallogenic evolution of the pericratonic rocks of east-central Alaska and adjacent Yukon. In Paleozoic Evolution and Metallogeny of Pericratonic Terranes at the Ancient Pacific Margin of North America, Canadian and Alaskan Cordillera. Edited by Colpron, M. and J.L. Nelson. Geological Association of Canada, Special Paper 45, pp. 25-74.

Ekhoff, J., Bundy, K., Schmitz, M. D., Davydov, V. I. and Over, D. J. 2013. U-Pb zircon geochronology in the Late Devonian Exshaw Formation: Global correlation with the Hangenberg black shale and extinction event. Geological Society of America, 125th Annual Meeting, Denver, CO, 45, no. 7: 581.

Enkelmann, E., Finzel, E. S. and Arkle, J. 2019. Deformation at the eastern margin of the Northern Canadian Cordillera: Potentially related to opening of the North Atlantic. Terra Nova, 31: 151-158. 
Eyster, A., Ferri, F., Schmitz, M. D. and Macdonald, F. A. 2018. One diamictite and two rifts: Stratigraphy and geochronology of the Gataga Mountain of northern British Columbia. American Journal of Science, 318: 167-207.

Fritz, W. H., Cecile, M. P., Norford, B. S., Morrow, D. and Geldsetzer, H. H. J. 1991. Cambrian to Middle Devonian assemblages, Chapter 7. In Geology of the Cordilleran Orogen in Canada. Edited by Gabrielse, H. and C. J. Yorath. Geological Survey of Canada, Geology of Canada, no. 4, (also Geological Society of America, The Geology of North America, v. G-2), pp. 151-218.

Gabrielse, H. 1967. Tectonic Evolution of the Northern Canadian Cordillera. Canadian Journal of Earth Sciences, 4: 271-298.

Gabrielse, H., Murphy, D. C. and Mortensen, J. K. 2006. Cretaceous and Cenozoic dextral orogenparallel displacements, magmatism, and paleogeography, north-central Canadian Cordillera. Paleogeography of the North American Cordillera: Evidence For and Against Large-Scale Displacements: Geological Association of Canada, Special Paper 46, pp. 255-276.

Gehrels, G. E. and Pecha, M. 2014. Detrital zircon U-Pb geochronology and Hf isotope geochemistry of Paleozoic and Triassic passive margin strata of western North America. Geosphere, 10: 49-65.

Gehrels, G. E., Dickinson, W. R., Ross, G. M., Stewart, J. H. and Howell, D. G. 1995. Detrital zircon reference for Cambrian to Triassic miogeoclinal strata of western North America. Geology, 23: 831834.

Gordey, S. P. 1990. Geology of the Tiny Island Lake map area (105M/16). Yukon Geological Survey, Open File 1990-2, scale 1:50,000.

Gordey, S. P. 2013a. Evolution of the Selwyn Basin region, Sheldon Lake (105J) and Tay River (105K) map areas, central Yukon Territory. Geological Survey of Canada, Bulletin 599, 176 p.

Gordey, S. P. 2013b. Geology, Selwyn Basin (105J and 105K), Yukon. Geological Survey of Canada, 2 maps at 1:250,000 scale (2149a and 2150a) and 1 sheet cross sections at 1:100,000 scale. 
Gordey, S. P. and Anderson, R. G. 1993. Evolution of the northern Cordilleran miogeocline, Nahanni map area (105I), Yukon and Northwest Territories. Geological Survey of Canada, Memoir 428, 214 p.

Gordey, S.P., Abbott, J.G., and Orchard, M.J. 1982. Devono-Mississippian (Earn Group) and younger strata in east-central Yukon. In Current Research, Part B, Geological Survey of Canada, Paper 82-1B, pp. 93-100.

Gordey, S. P., Abbott, J. G., Tempelman-Kluit, D. J. and Gabrielse, H. 1987. "Antler" clastics in the Canadian Cordillera. Geology, 15: 103-107.

Gordey, S. P., Geldsetzer, H. H. J., Morrow, D. W., Bamber, E. W., Henderson, C. M., Richards, B. C., McGugan, A., Gibson, D. W. and Poulton, T. P. 1991. Part A. Ancestral North America, Upper Devonian to Middle Jurassic Assemblages (Chapter 8). In Geology of the Cordilleran Orogen in Canada. Edited by Gabrielse, H. and C. J. Yorath. Geological Survey of Canada, Geology of Canada, No.4, (also Geological Society of America, The Geology of North America, v. G-2), pp. 221-329.

Irwin, S. E. B. and Orchard, M. J. 1991. Upper Devonian - Lower Carboniferous conodont biostratigraphy of the Earn Group and overlying units, northern Canadian Cordillera. In Ordovician to Triassic conodont paleontology of the Canadian Cordillera. Edited by Orchard, M. J. and A. D. McCracken. Geological Survey of Canada, Bulletin 417, pp. 185-213.

Jennings, D. S. and Jilson, G.A. 1986. Geology and Sulphide deposits of Anvil Range, Yukon. In Mineral Deposits of Northern Cordillera, Edited by J.A. Morin. Canadian Institute of Mining and Metallurgy, Special Volume 37, pp. 319-361.

Johnson, J. G. and Pendergast, A. 1981. Timing and mode of emplacement of the Roberts Mountains allochthon, Antler orogeny. Geological Society of America Bulletin, 92: 648-658.

Kent, D. M. 1994. Paleogeographic evolution of the cratonic platform - Cambrian to Triassic. In Geologic Atlas of the Western Canada Sedimentary Basin. Edited by Mossop, G. and I. Shestin. Alberta Research Council and Canadian Society of Petroleum Geologists, pp. 69-86. 
Kraft, J. L. 2013. Stratigraphy, paleogeography and tectonic evolution of early Paleozoic to Triassic pericratonic strata in the northern Kootenay Arc, southeastern Canadian Cordillera. PhD thesis, Department of Earth and Atmospheric Sciences, University of Alberta, Edmonton, AB, $361 \mathrm{p}$.

Lane, L. S. 2007. Devonian-Carboniferous paleogeography and orogenesis, northern Yukon and adjacent Arctic Alaska. Canadian Journal of Earth Sciences, 44: 679-694.

Lemieux, Y., Hadlari, T. and Simonetti, A. 2011. Detrital zircon geochronology and provenance of Devono-Mississippian strata in the northern Canadian Cordilleran miogeocline. Canadian Journal of Earth Sciences, 48: 515-541.

Ludwig, K. R. 2003. Isoplot 3.0, A geochronological toolkit for Microsoft Excel. Berkley Geochronology Center, Special Publication No. 4, 70 p.

Macdonald, F. A., Schmitz, M. D., Strauss, J. V., Halverson, G. P., Gibson, T. M., Eyster, A., Cox, G., Mamrol, P. and Crowley, J. L. 2018. Cryogenian of Yukon. Precambrian Research, 319: 114-143.

Mair, J. L., Hart, C. J. R. and Stephens, J. R. 2006. Deformation history of the northwestern Selwyn Basin, Yukon, Canada: Implications for orogen evolution and mid-Cretaceous magmatism. Geological Society of America Bulletin, 118: 304-323.

Manor, M. J., Piercey, S. J. and Wall, C. J. 2019. New U-Pb zircon geochronology and Lu-Hf isotope constraints on the episodic evolution of felsic rocks in the Finlayson Lake district, Yukon. Cordilleran Tectonics Workshop 2019, Simon Fraser University, Vancouver, B.C., p. 40.

Mazzotti, S. and Hyndman, R. D. 2002. Yakutat collision and strain transfer across the northern Canadian Cordillera. Geology, 30: 495-498.

McLennan, S. M. 2001. Relationships between the trace element composition of sedimentary rocks and upper continental crust. Geochemistry, Geophysics, Geosystems, 2: Paper 2000 GC000109.

Miall, A. D. 2019. The Paleozoic western craton margin. In The Sedimentary Basins of the United States and Canada, 2nd edition. Edited by Miall, A. D. Elsevier, pp. 239-266. 
Middlemost, E. A. 1994. Naming materials in the magma/igneous rock system. Earth-Science Reviews, 37: 215-224.

Monger, J. W. H. and Price, R. A. 2002. The Canadian Cordillera: Geology and tectonic evolution. Canadian Society of Exploration Geophysicists Recorder, 27: 17-36.

Mortensen, J.K. 1992. Pre-mid-Mesozoic tectonic evolution of the Yukon-Tanana terrane, Yukon and Alaska. Tectonics, 11: 836-853.

Mortensen, J.K., Hart, C.J.R., Murphy, D.C., and Heffernan, S., 2000. Temporal evolution of early and mid-Cretaceous magmatism in the Tintina Gold Belt. In The Tintina Gold Belt: Concepts, Exploration, and Discoveries. Edited by T.L. Tucker and M.T. Smith, British Columbia and Yukon Chamber of Mines, Special Volume 2, pp. 49-58.

Murphy, D. C., Mortensen, J. K., Piercey, S. J., Orchard, M. J. and Gehrels, G. E. 2006. Mid-Paleozoic to early Mesozoic tectonostratigraphic evolution of Yukon-Tanana and Slide Mountain terranes and affiliated overlap assemblages, Finlayson Lake massive sulphide district, southeastern Yukon. In Paleozoic Evolution and Metallogeny of Pericratonic Terranes at the Ancient Pacific Margin of North America, Canadian and Alaskan Cordillera. Edited by Colpron, M. and J. L. Nelson. Geological Association of Canada, Special Paper 45, pp. 75-105.

Nelson, J. L., Colpron, M., Piercey, S. J., Dusel-Bacon, C., Murphy, D. C. and Roots, C. F. 2006. Paleozoic tectonic and metallogenic evolution of the pericratonic terranes in Yukon, northern British Columbia and eastern Alaska. In Paleozoic evolution and metallogeny of pericratonic terranes at the ancient Pacific margin of North America, Canadian and Alaskan Cordillera. Edited by Colpron, M. and J. L. Nelson. Geological Association of Canada, Special Paper 45, pp. 323-360.

Nelson, J. L., Colpron, M., and Israel, S. 2013. The Cordillera of British Columbia, Yukon and Alaska: Tectonics and Metallogeny. In Tectonics, metallogeny, and discovery: the North American cordillera and similar accretionary settings. Edited by Colpron, M., Bissig, T., Rusk, B. G. and Thompson, J. F. Society of Economic Geologists, Special Publication 17, pp. 53-109.

Ogg, J., and Lugowski, A. 2020. Time Scale Creator, ver. 7.0, www.tscreator.org. 
Paradis, S., Bailey, S. L., Creaser, R. A., Piercey, S. J., Schiarizza, P., Colpron, M. and Nelson, J. 2006. Paleozoic magmatism and syngenetic massive sulphide deposits of the Eagle Bay assemblage, Kootenay terrane, southern British Columbia. Paleozoic evolution and metallogeny of pericratonic terranes at the ancient Pacific margin of North America, Canadian and Alaskan Cordillera: Geological Association of Canada, Special Paper 45, pp. 383-414.

Pearce, J. A. 1996. A user's guide to basalt discrimination diagrams. In Trace element geochemistry of volcanic rocks: Applications for massive sulphide exploration. Edited by Wyman, D. A. Geological Association of Canada, Short Course Notes, Volume 12, pp. 79-113.

Pearce, J. A. 2008. Geochemical fingerprinting of oceanic basalts with applications to ophiolite classification and the search for Archean oceanic crust. Lithos, 100: 14-48.

Pearce, J. A., Harris, N. B. W. and Tindle, A. G. 1984. Trace element discrimination diagrams for the tectonic interpretation of granitic rocks. Journal of Petrology, 25: 956-983.

Piercey, S.J. and Colpron, M. 2009. Composition and provenance of the Snowcap assemblage, basement to the Yukon-Tanana terrane, northern Cordillera: Implications for Cordilleran crustal growth. Geosphere, 5(5): 439-464.

Piercey, S. J., Murphy, D. C., Mortensen, J. K. and Creaser, R. 2004. Mid-Paleozoic initiation of the northern Cordilleran marginal backarc basin: Geologic, geochemical, and neodymium isotope evidence from the oldest mafic magmatic rocks in the Yukon-Tanana terrane, Finlayson Lake distric, southeast Yukon, Canada. Geological Society of America Bulletin, 116: 1087-1106.

Piercey, S. J., Nelson, J. L., Colpron, M., Dusel-Bacon, C., Roots, C. F. and Simard, R.-L. 2006. Paleozoic magmatism and crustal recycling along the ancient Pacific margin of North America, northern Cordillera. In Paleozoic Evolution and Metallogeny of Pericratonic Terranes at the Ancient Pacific Margin of North America, Canadian and Alaskan Cordillera. Edited by Colpron, M. and J. L. Nelson. Geological Association of Canada, Special Paper 45, pp. 281-322.

Pigage, L.C., 2000. Geological map of Mount Mye (105K/6 E), central Yukon (1:25000 scale). Indian and Northern Affairs Canada/Department of Indian and Northern Development: Exploration and Geological Services Division, Open File 2000-7, scale 1:25,000. 
Pigage, L. C. 2004. Bedrock geology compilation of the Anvil District (parts of 105K/2, 3, 5, 6,7 and 11), central Yukon. Yukon Geological Survey, Bulletin 15, 103 p.

Pigage, L. C., Roots, C. F. and Abbott, J. G. 2015. Regional bedrock geology for Coal River map area (NTS 105D), southeast Yukon. Yukon Geological Survey, Bulletin 17, 155 p.

Powell, J., Schneider, D., Stockli, D. and Fallas, K. 2016. Zircon (U-Th)/He thermochronology of Neoproterozoic strata from the Mackenzie Mountains, Canada: Implications for the Phanerozoic exhumation and deformation history of the northern Canadian Cordillera. Tectonics, 35(3): 663-689.

Rasmussen, K. L. 2013. The timing, composition, and petrogenesis of syn- to post-accretionary magmatism in the northern Cordilleran miogeocline, eastern Yukon and southwestern Northwest Territories. University of British Columbia.

Richards, B. C., Barclay, J. E., Bryan, D., Hartling, A., Henderson, C. M. and Hinds, R. C. 1994. Carboniferous strata of the Western Canada Sedimentary Basin. In Geologic Atlas of the Western Canada Sedimentary Basin. Edited by Mossop, G. and I. Shestin. Alberta Research Council and Canadian Society of Petroleum Geologists, pp. 221-250.

Richards, B.C., Ross, G. M. and Utting, J. 2002. U-Pb geochronology, lithostratigraphy and biostratigraphy of tuff in the upper Fammenian to Tournaisian Exshaw Formation: Evidence for a mid-Paleozoic magmatic arc on the northwestern margin of North America. In Carboniferous and Permian of the World. Edited by Hills, L. V., C. M. Henderson and E. W. Bamber. Canadian Society of Petroleum Geologists, Memoir 19, pp. 158-207.

Roddick, J. A. and Green, L. H. 1961. Tay River map area, Yukon Territory. Geological Survey of Canada, Map 13-1961, scale 1:253,440.

Roots, C. F. 1997. Geology of the Mayo map area, Yukon Territory (105M). Exploration and Geological Services Division, Yukon, Indian and Northern Affairs Canada, Bulletin 7, 81 p.

Ross, P.-S. and Bédard, J. H. 2009. Magmatic affinity of modern and ancient subalkaline volcanic rocks determined from trace-element discriminant diagrams. Canadian Journal of Earth Sciences, 46: 823839. 
Rubin, C. M., Miller, M.M., and Smith, G.M. 1990. Tectonic development of Cordilleran mid-Paleozoic volcano-plutonic complexes; Evidence for convergent margin tectonism. In Transverse geochemical variations across the Antarctic Peninsula: implications for the genesis of calc-alkaline magmas. Edited by Saunders, A. D., Tarney, J. and S.D. Weaver. Earth and Planetary Science Letters, 46: 344-360.

Sun, S. S. and McDonough, W. F. 1989. Chemical and isotopic systematics of oceanic basalts:

implications for mantle composition and processes. In Magmatism in ocean basins. Edited by Saunders, D. and M. J. Norry. Geological Society of London, Special Publication 42, pp. 313-345.

Tempelman-Kluit, D. J. 2012. Geology of Quiet Lake and Finlayson Lake map areas, south-central Yukon - An early interpretation of bedrock stratigraphy and structure. Geological Survey of Canada, Open File 5487, 103 p.

Thorsteinsson, R. and Tozer, E. T. 1970. Geology of the Arctic Archipelago. In Geology and Economic Minerals of Canada. Edited by Douglas, R. J. W. Geological Survey of Canada, Economic Geology Report 1, pp. 549-590.

Trettin, H. P., Okulitch, A. V., Harrison, J. C., Brent, T. A., Fox, F. G., Packard, J. J., Smith, G. P. and Zolnai, A. I. 1991. Silurian - Early Carboniferous deformational phases and associated metamorphism and plutonism, Arctic Islands. In Geology of the Innuitian Orogen and Arctic Platform of Canada and Greenland. Edited by Trettin, H. P. Geological Survey of Canada, Geology of Canada 3, also Geological Society of America, The Geology of North America, v. E, pp. 293-341.

Winchester, J. A. and Floyd, P. A. 1977. Geochemical discrimination of different magma series and their differentiation products using immobile elements. Chemical Geology, 20: 325-343.

Yukon Geological Survey 2020a. Yukon geochronology database. Yukon Geological Survey, http://data.geology.gov.yk.ca/Compilation/22, accessed: April 21, 2020.

Yukon Geological Survey 2020b. Yukon Digital Bedrock Geology. Yukon Geological Survey, http://datatest.geology.gov.yk.ca/Compilation/3, accessed: March 30, 2020. 
Yukon Geological Survey 2020c. Yukon lithogeochemistry database. Yukon Geological Survey, http://data.geology.gov.yk.ca/Compilation/35, accessed: June 21, 2020.

Figure captions

Figure 1: Terrane map of Yukon and adjacent parts of Alaska, British Columbia (BC) and Northwest Territories (NWT). Modified after Colpron and Nelson (2011). Red polygon shows outline of Figure 2; black stars indicate localities discussed in the text. SL - Sheldon Lake area. Hatched area near the northern edge of Selwyn basin indicates approximate extent of area where Earn Group is unconformable on lower Cambrian and older Hyland Group. Inset shows outline of Figure 1 in the northern Cordillera, and location of Kootenay terrane (K) and Exshaw Formation (E) in the southeastern Canadian Cordillera. Blue region in inset shows distribution of parautochthonous continental margin rocks; pink regions are accreted allochthonous terranes. The map was created using Arcmap version 10.7.1 and assembled from the following data sources: hillshades (Government of Yukon).

Figure 2: Simplified geological map of the Glenlyon-Tay River area. The locations of U-Pb samples (black dots) and fossil collections (open circles) are shown here and in Figure 5. Line of cross sections in Figure 3 are also shown. Black boxes show the outline of maps in Figure 5 which show details of Earn Group stratigraphy. Geologic map after Cobbett $(2015,2016 b, 2016 c)$. The map was created using Arcmap version 10.7.1 and assembled from the following data sources: waterbodies and watercourse (Government of Yukon).

Figure 3. Geological cross sections illustrating structural panels within the Glenlyon-Tay River area. Abbreviations, unit patterns and colours, and lines of sections are shown in Figure 2.

Figure 4: Stratigraphy of the Glenlyon-Tay River area. The two columns show nomenclature and correlation for metamorphosed lower Cambrian to Middle Devonian strata in the hanging wall of the 
Twopete thrust (Anvil district) and unmetamorphosed strata in the footwall of the Twopete thrust (Selwyn basin).

Figure 5: Detailed geological maps showing the internal stratigraphy of the Earn Group in the southeastern (A) and central (B) parts of the Glenlyon-Tay River area. Map locations are shown in Figure 2. Geologic maps after Cobbett $(2015,2016 b, 2016 c)$. The map was created using Arcmap version 10.7.1 and assembled from the following data sources: waterbodies and watercourse (Government of Yukon).

Figure 6: Schematic stratigraphy of the Earn Group in the Stokes thrust sheet illustrating variations in lithofacies. Approximate positions of U-Pb samples and fossil collections are shown to the right of columns. Datum for the three sections is the ca. 363 Ma tuff (shown by red lines). Dashed blue line indicates contact between lower and upper Earn Group.

Figure 7: Representative photographs of Upper Devonian volcanic rocks in the Earn Group of the Glenlyon-Tay River area. a) Beige weathering welded tuff with fiamme exposed along Menzie Creek (DMEua). b) Quartz-feldspar crystal tuff, southeastern part of the area (DMEuct). c) Amygdaloidal andesite flow from the southeastern part of the Glenlyon-Tay River area (DMEut).

Figure 8: Photomicrographs of crystal-lithic tuff samples from the Glenlyon-Tay River area: A, C, D, plane-polarized light (PPL) and B, cross-polarized light (XPL) a) Angular quartz and feldspar (altered to sericite) grains in fine-grained matrix in sample 13RC129 (DMEuct), PPL. b) Same view of 13RC129 in XPL shows sericitic alteration of feldspar (Ser). c) Quartz and sericite-altered feldspar grains in a finegrained matrix, sample 13RC280 (DMEu), PPL. Biotite (Bt) porphyroblast is related to contact metamorphism of the Anvil batholith. d) Foliated crystal tuff, sample 13RC112, from the southeastern part of the area (PPL). The foliation is defined by elongate grains of chlorite (Chl), sericite (Ser) and opaque minerals.

Figure 9: Photographs of Late Devonian intrusive rocks from the Glenlyon-Tay River area. a) Typical exposures of Late Devonian porphyritic diorite $(\mathrm{Dg})$ characterized by steep-sided rocky knobs in heavily treed landscape. Photograph shows area approximately $8 \mathrm{~km}$ south of Crystal Peak and location of sample 16RC061. b) Light green weathering, green-grey fresh, medium-grained pyroxeneplagioclase-phyric diorite northwest of Mount Menzie (Dg - 16RC110; Figs. 2 and 5b).

Figure 10: Photomicrographs of porphyritic diorite samples from the Glenlyon-Tay River area. a) Sample 18RC081 in XPL. b) Sample 16RC061 in PPL and XPL (c). Clinopyroxene partially altered to chlorite and amphibole in a feldspar groundmass. d) Photomicrograph of an altered porphyritic 
diorite (sample 15RC144, PPL). Altered pyroxene phenocrysts in groundmass of feldspar that are square minerals in cross section. e) Photomicrograph from sample 16RC110 in PPL and XPL (f). Clinopyroxene and feldspar phenocrysts in a groundmass of dominantly feldspar. g) Sample 13RC108 in PPL and XPL (h). Clinopyroxene and altered orthopyroxene (?) phenocrysts in a groundmass comprising feldspar. h) Amph - amphibole; Cal - calcite; Cpx - clinopyroxene; Fsp - feldspar; Opx orthopyroxene; Px-pyroxene.

Figure 11. Geochemical classification diagrams for Late Devonian diorite and tuff of the Glenlyon-Tay River area. a) Total alkali vs. silica diagram of Middlemost (1994) for intrusive rocks; b) Zr/Ti vs. Nb/Y diagram of Pearce (1996; modified after Winchester and Floyd 1977); c) La-Yb diagram of Ross and Bédard (2009); d) Ta-Yb diagram of Pearce et al. (1984). ORG- ocean ridge granites, VAG - volcanic arc granites, WPG - within plate granites, syn-COLG - collisional granites. Samples from other Earn Group volcanic rocks at the Marg deposit are shown for comparison (data from Yukon Geological Survey 2020c).

Figure 12. a) Primitive mantle-normalized trace-element patterns for Late Devonian diorite and tuff from the upper Earn Group; values of Sun and McDonough (1989). b) Rare-earth element patterns normalized to upper continental crust values of McLennan (2001).

Figure 13: Select photographs of brachiopods from the Earn Group in the Glenlyon-Tay River area. a) Pragian to Emsian Johnsonetes cf. J. filistriatus (Walcott 1884) from siltstone in the lower Earn Group (15RC178). b) Frasnian Eleutherokomma sp. collected on Earn Mountain (16RC087). c) Famennian Schizophoria sp. from a creek exposure, east of Crystal Peak (16RC053). Scale bars are $1 \mathrm{~cm}$.

Figure 14. Ranked plot of $206 \mathrm{~Pb} / 238 \mathrm{U}$ dates from single zircon grains analyzed by the CA-TIMS method for tuff and porphyritic diorite samples (Table 3; S3). Vertical black bars are dates included in the weighted mean calculations, and white boxes are older dates interpreted to be xenocrysts. Light grey boxes show the weighted mean date with extent of 2] error. All errors are 2]; errors on the weighted mean dates are the internal errors. Discordant, older dates from 13RC107 and 16RC061 are not shown here.

Figure 15. Ranked plot of $206 \mathrm{~Pb} / 238 \mathrm{U}$ dates for two samples of porphyritic diorite analysed by LAICPMS. Only Paleozoic dates are shown here (Table 3; S4). Weighted mean dates are indicated by light grey boxes. All errors are 2?.

Figure 16: Probability density plots of U-Pb dates from detrital zircons recovered from three sandstones of the upper Earn Group and analyzed by LA-ICPMS. The youngest peak in 13RC107 was 
scaled down $50 \%$. Small inset for each sample shows ranked plot of $206 \mathrm{~Pb} / 238 \mathrm{U}$ dates for zircon grains from the youngest population that were further analyzed by CA-TIMS to establish the maximum depositional age (MDA) more precisely. The weighted mean for $16 R C 085$ (shown by light grey box) and all probability density plots were calculated with Isoplot 3.0 (Ludwig 2003). Dates in ranked plots are given with 2

? internal errors.

Figure 17: Summary of chronological constraints for strata of the Earn Group in the Glenlyon-Tay River area. Fossil age constraints from other areas discussed in the text are shown on the right (Sheldon Lake, Nahanni, Macmillan Pass). Hatched bar in the Macmillan Pass column shows approximate age range of mafic volcanic rocks in this area. Purple bars on the left indicate dates for other igneous rocks regionally associated with the Earn Group in Yukon (Marg and Pelly). Grey polygon at the far-left shows the relative probability distribution (mirrored) for 141 igneous U-Pb dates from the Yukon-Tanana terrane in Yukon (YTT). Data for Marg, Pelly and YTT U-Pb dates are from Yukon Geological Survey (2020a). Timescale generated using Time Scale Creator 7.0 (Ogg and Lugowski 2020).

Tables

Table 1. Major and trace element geochemistry for tuff and diorite samples from the Glenlyon-Tay River area, central Yukon.

Table 2. Fossil collections from the Earn Group in Glenlyon-Tay River area, central Yukon

Table 3. Summary of U-Pb geochronological results for samples from the Glenlyon-Tay River area 


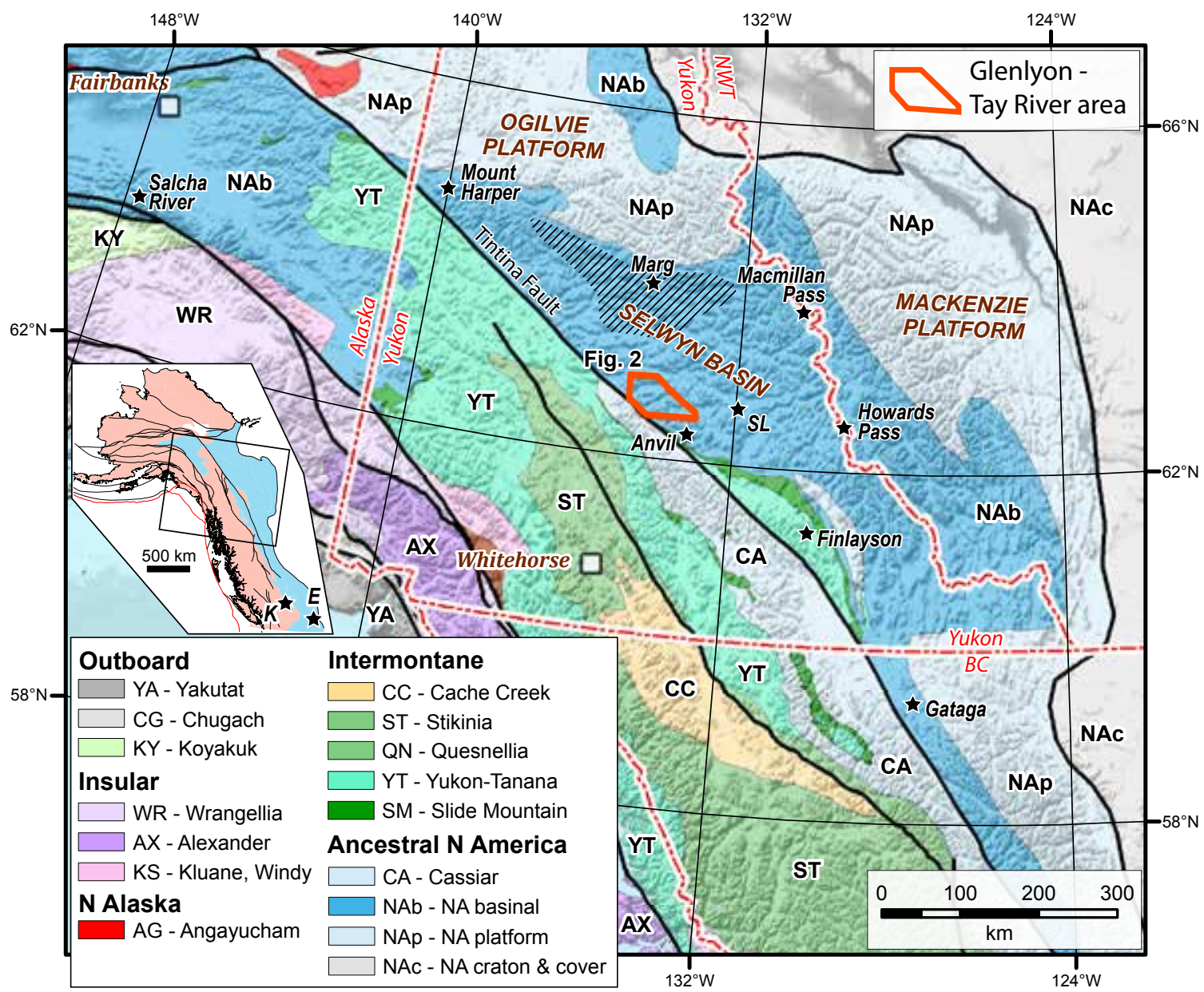

Figure 1 


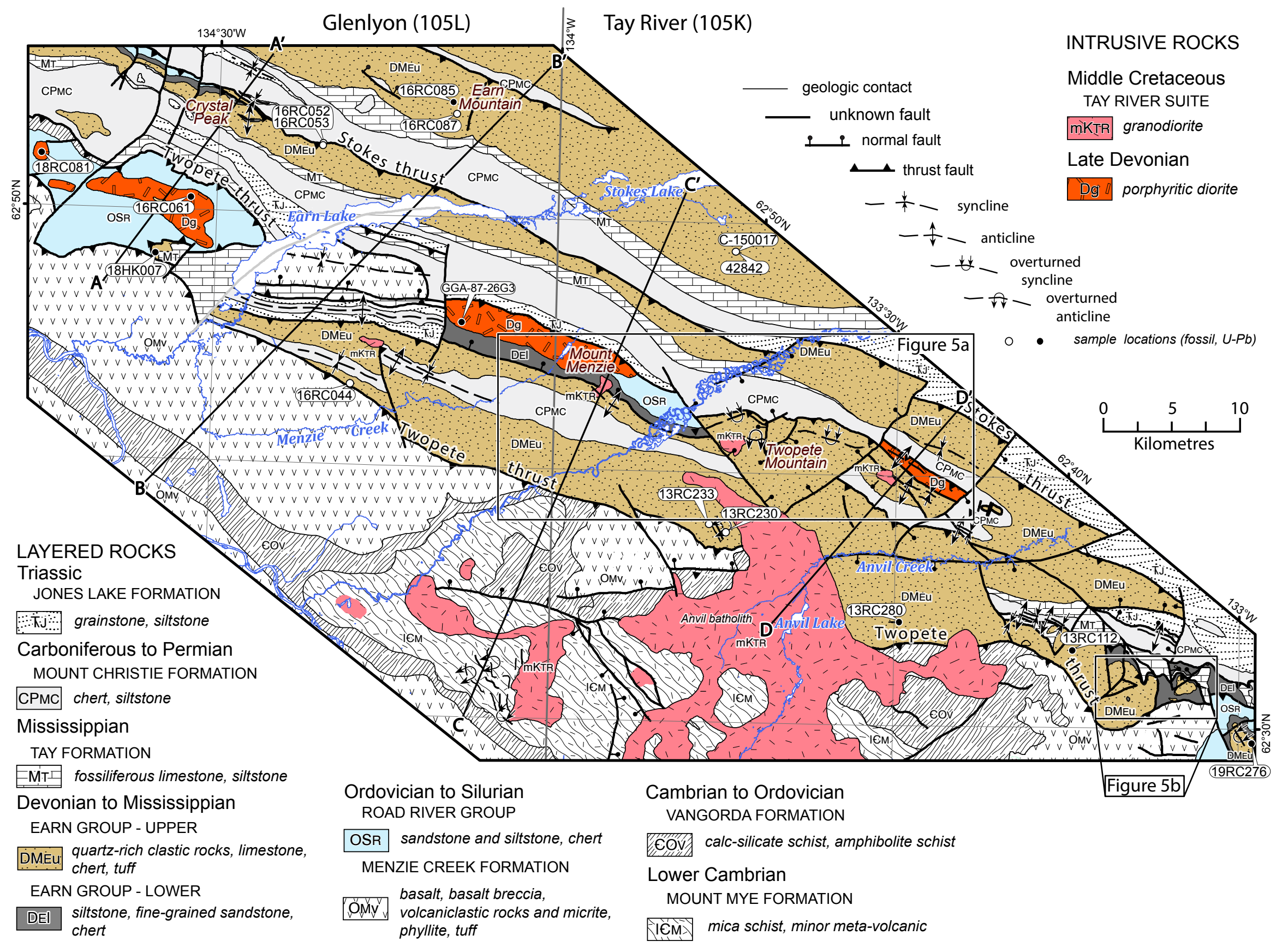



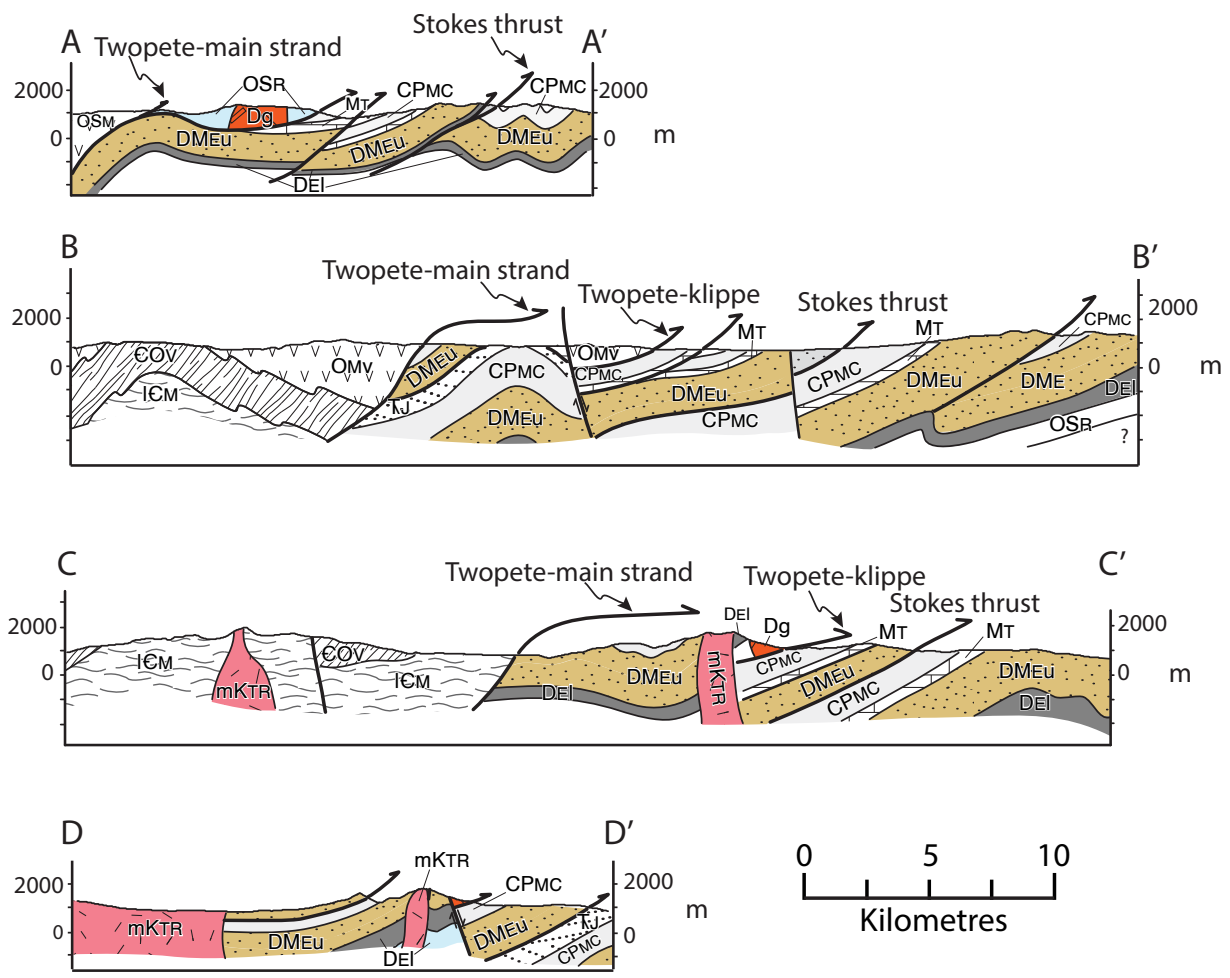

Figure 3 


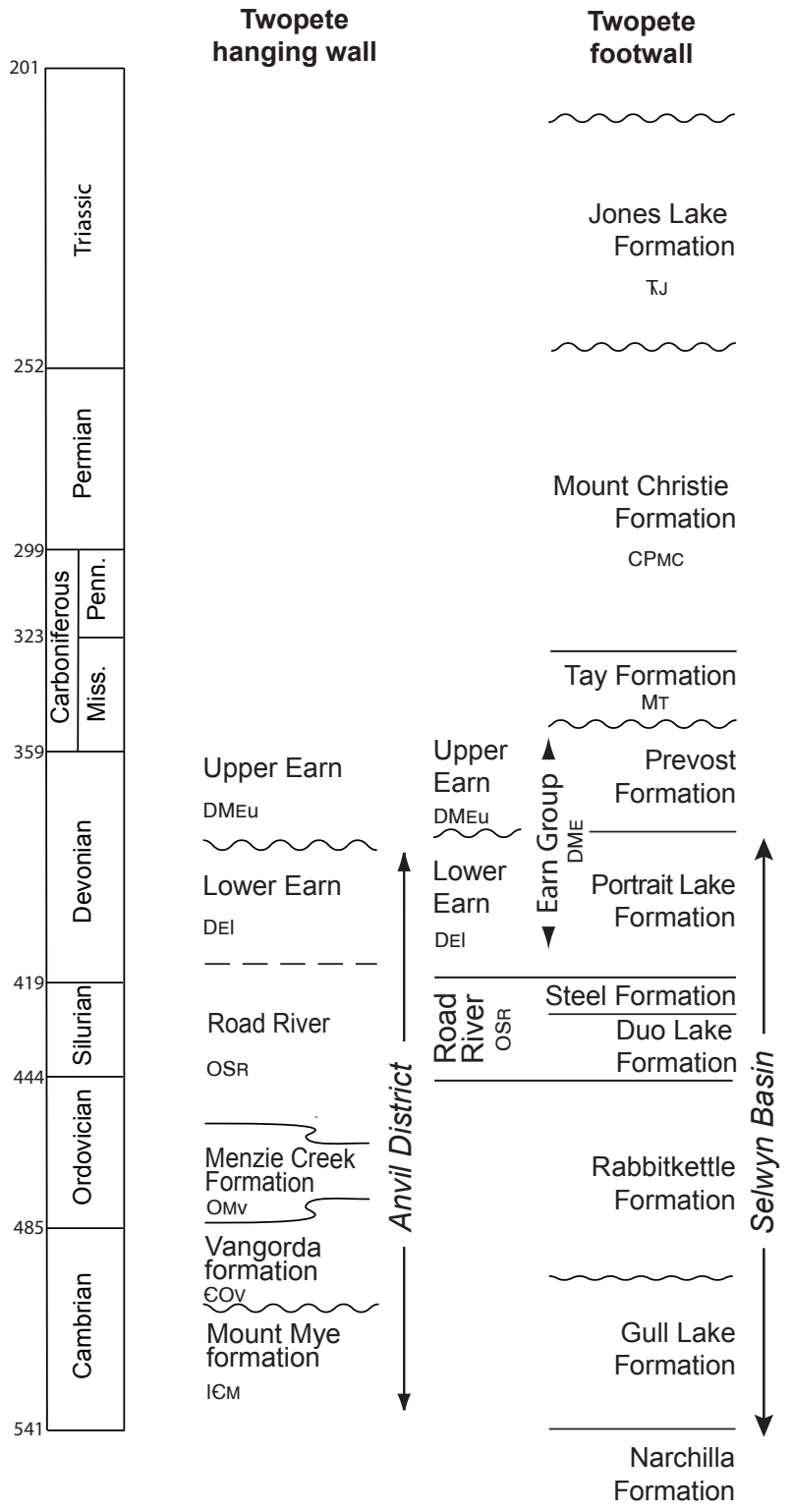




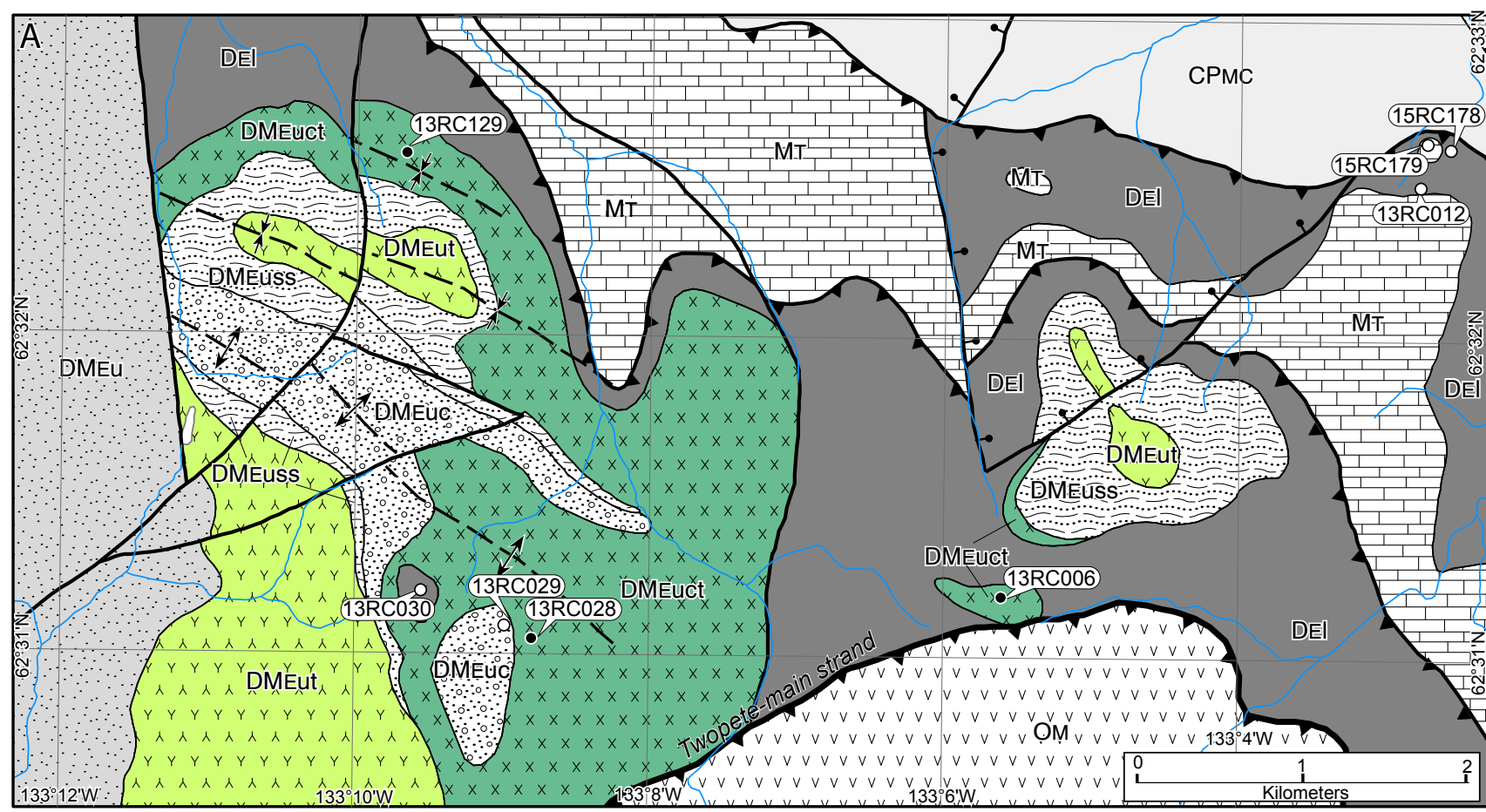

Jones Lake Formation

TJ grainstone, siltstone

Mount Christie Formation

$\square$ CPMC chert, siltstone

Tay Formation

MT fossiliferous limestone,

$\because \because \cdots$ : limestone debris flow and thin

beddedquartz-rich grainstone

$\therefore$ DMEu undivided upper Earn Group

$\therefore$ DMEua quartzose siltstone, quartz arenite

DMEch black chert

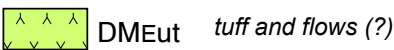

DMEuss siltstone interbedded with

... fine-grained sandstone

a d DMEuc chert pebble conglomerate

$\left.\begin{array}{ccc}x & x & x \\ x & x & x\end{array}\right]$ DMEuct crystal tuff

Earn - lower Road River Group

$\square$ DEI $\square$ OSR

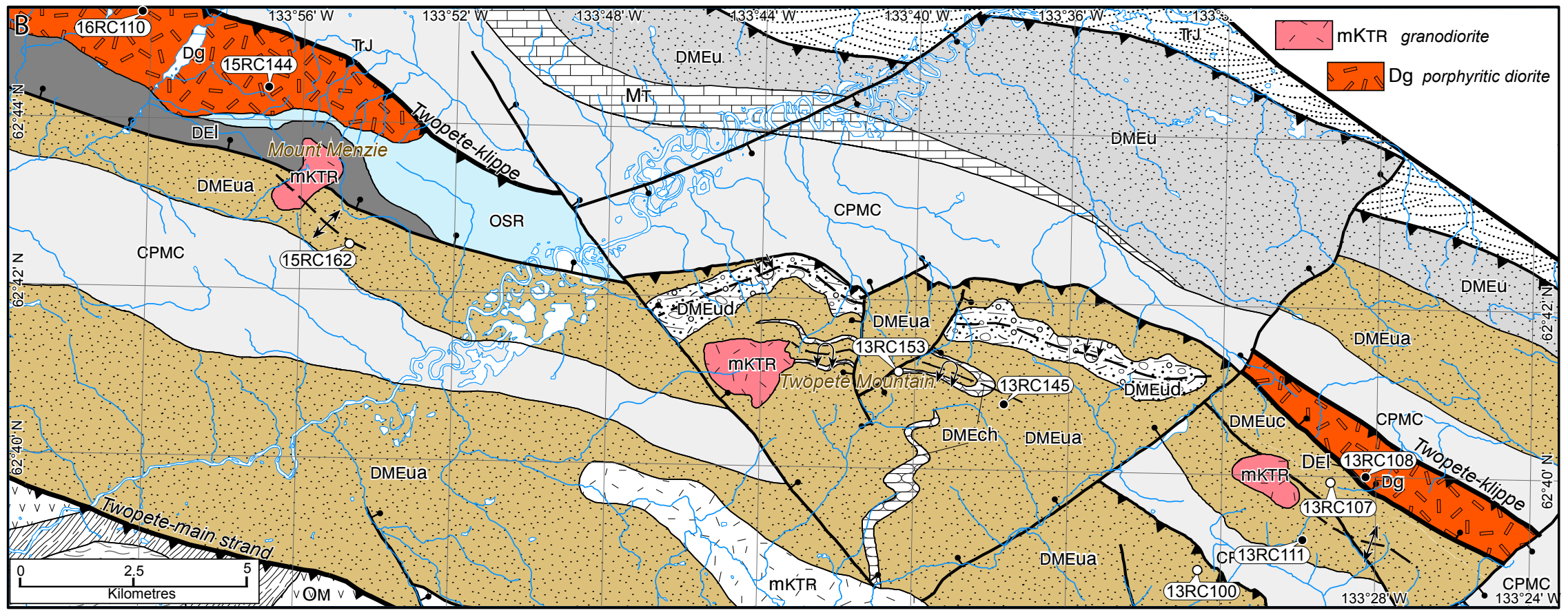


(north of Earn Lake)
NORTHWEST

CENTRAL

(between Anvil Creek
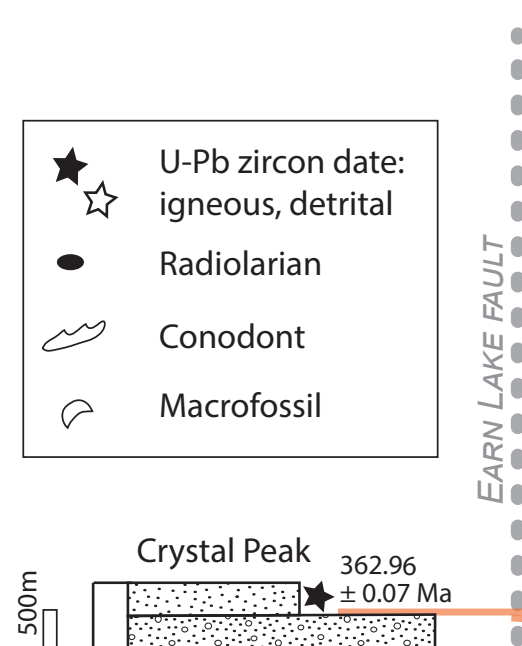
and Earn Lake)

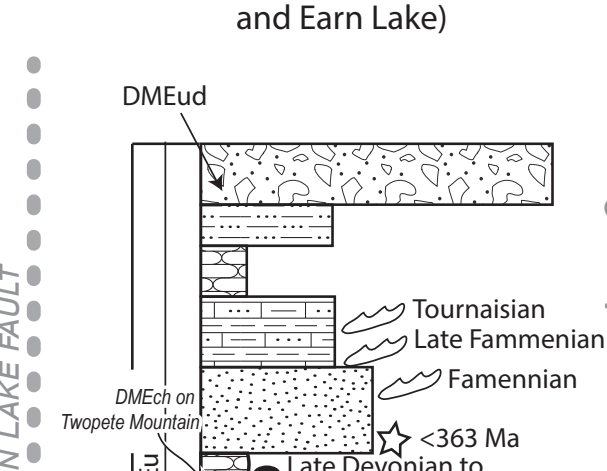

峞

Q Late Devonian to

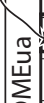

SOUTHEAST

(south of Anvil Creek)

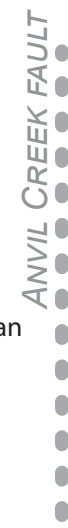

势

$<$ Late Devonian0 (Frasnian) Late Devonian
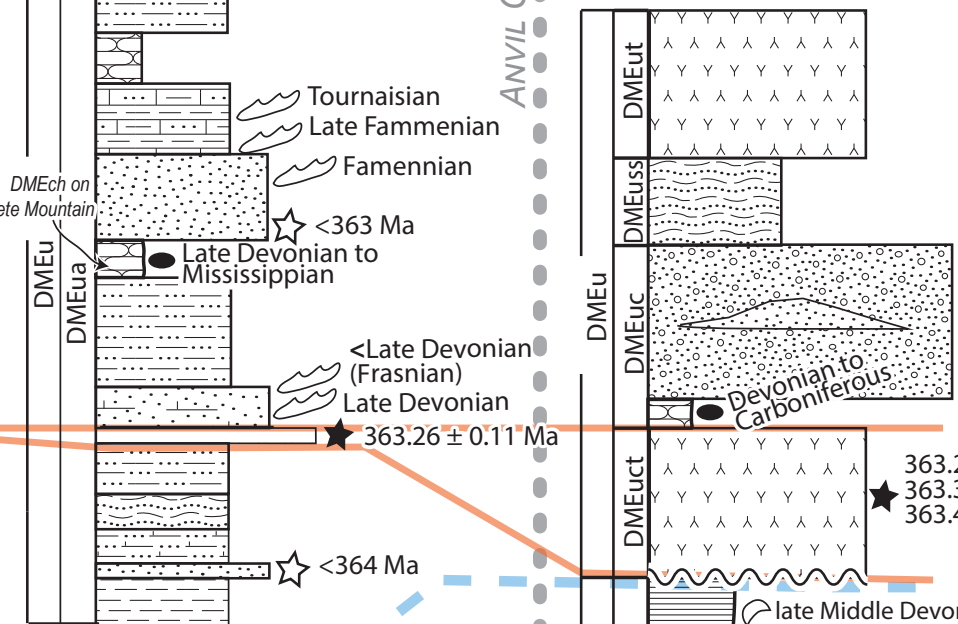

Base not exposed \begin{tabular}{|l|l|l|l|l|}
1 & 1 & 1
\end{tabular}

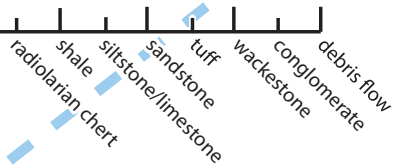

एँ

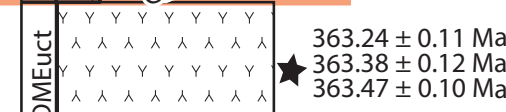

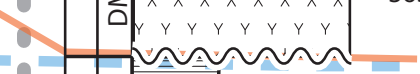

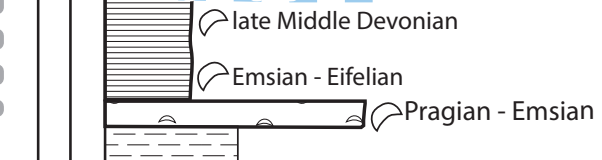

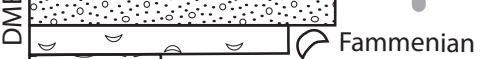

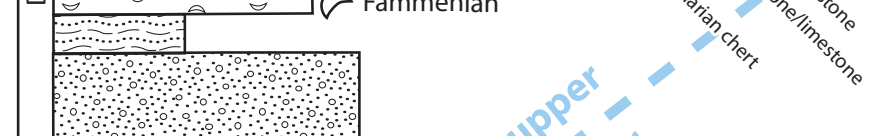

0
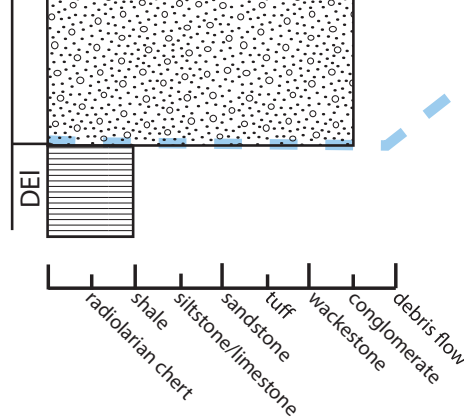

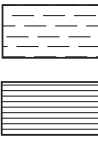

siltstone

shale

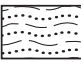

siltstone interbedded

with sandstone

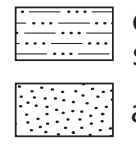

quartz-rich

siltstone

conglomerate

bul limestone debris flow $\frac{x}{x^{x}}$ chert

$\begin{array}{lll}\nabla & \quad \begin{array}{l}\text { fossiliferous } \\ \text { wackestone }\end{array}\end{array}$

$\ldots \ldots$ silty limestone

with siltstone

calcite cemented quartz-rich sandstone

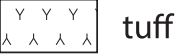

एव pyroxene porphyry

Fig. 6 

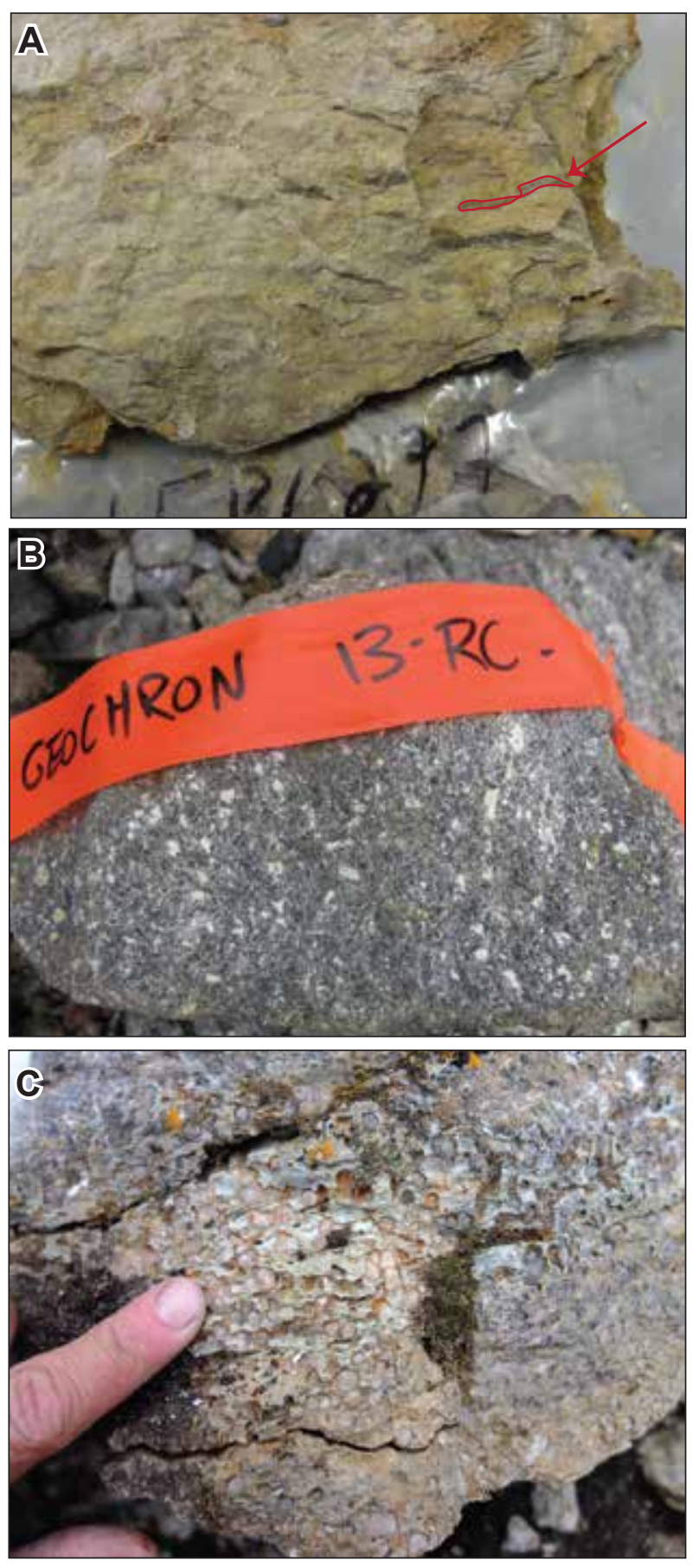

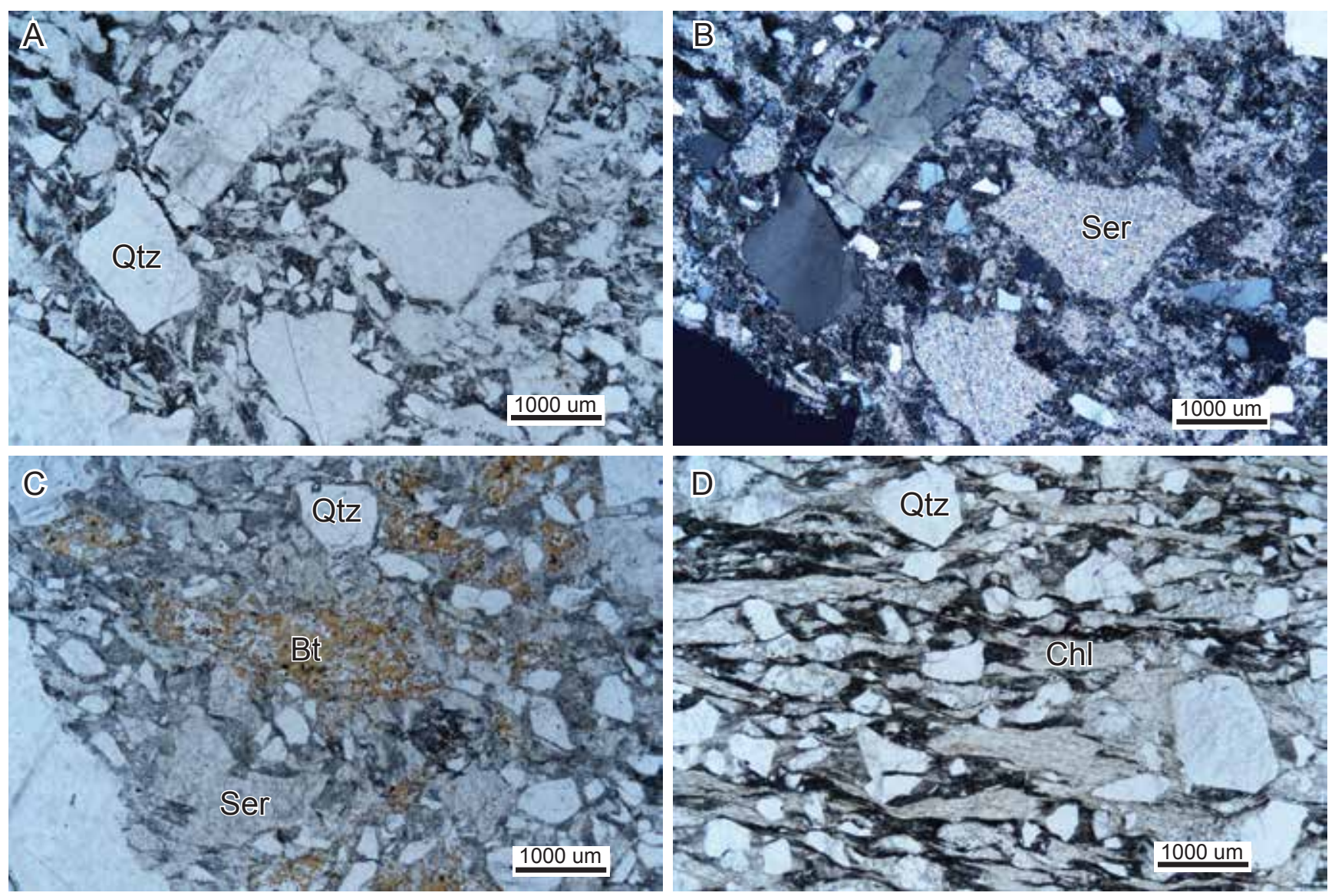

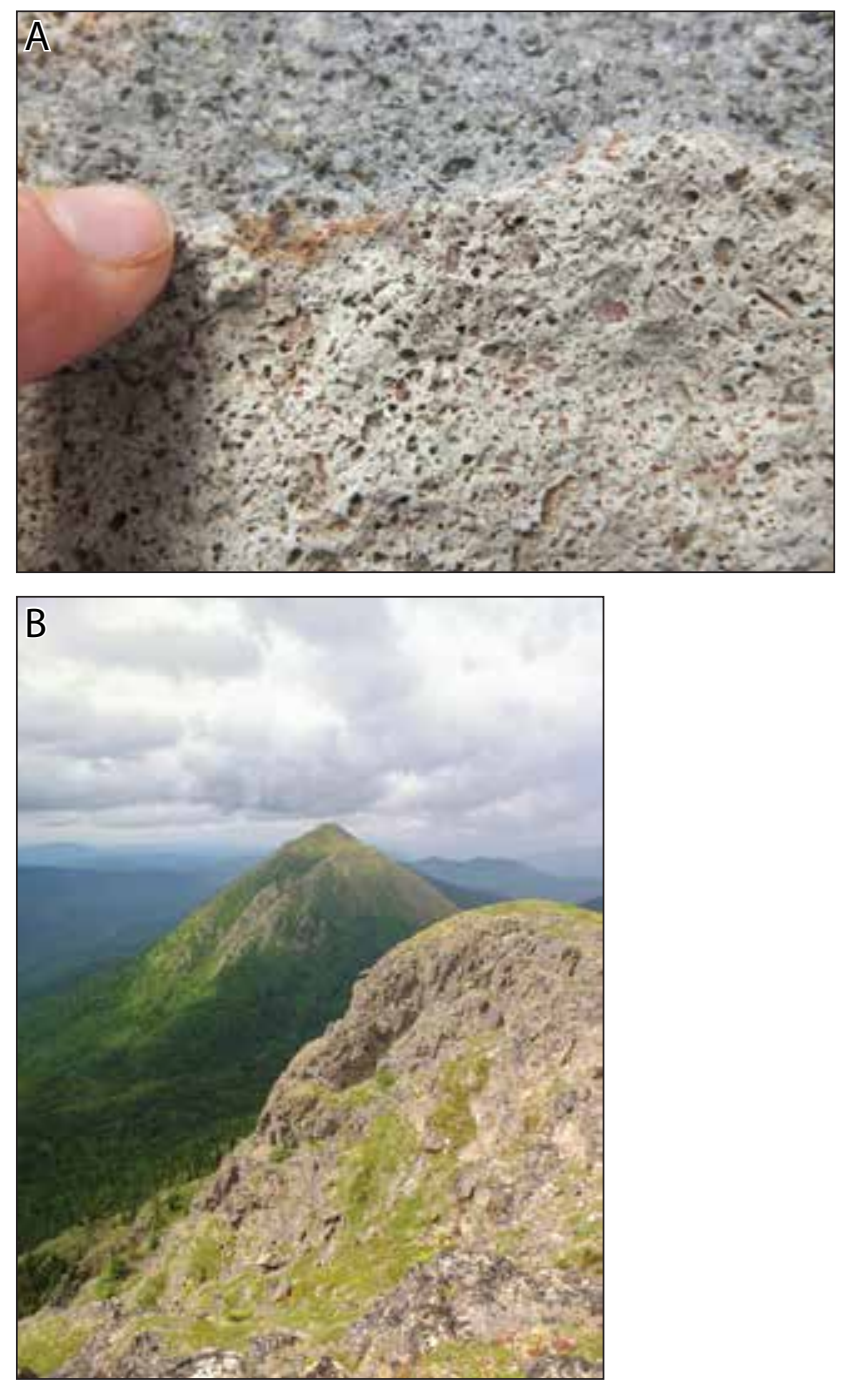

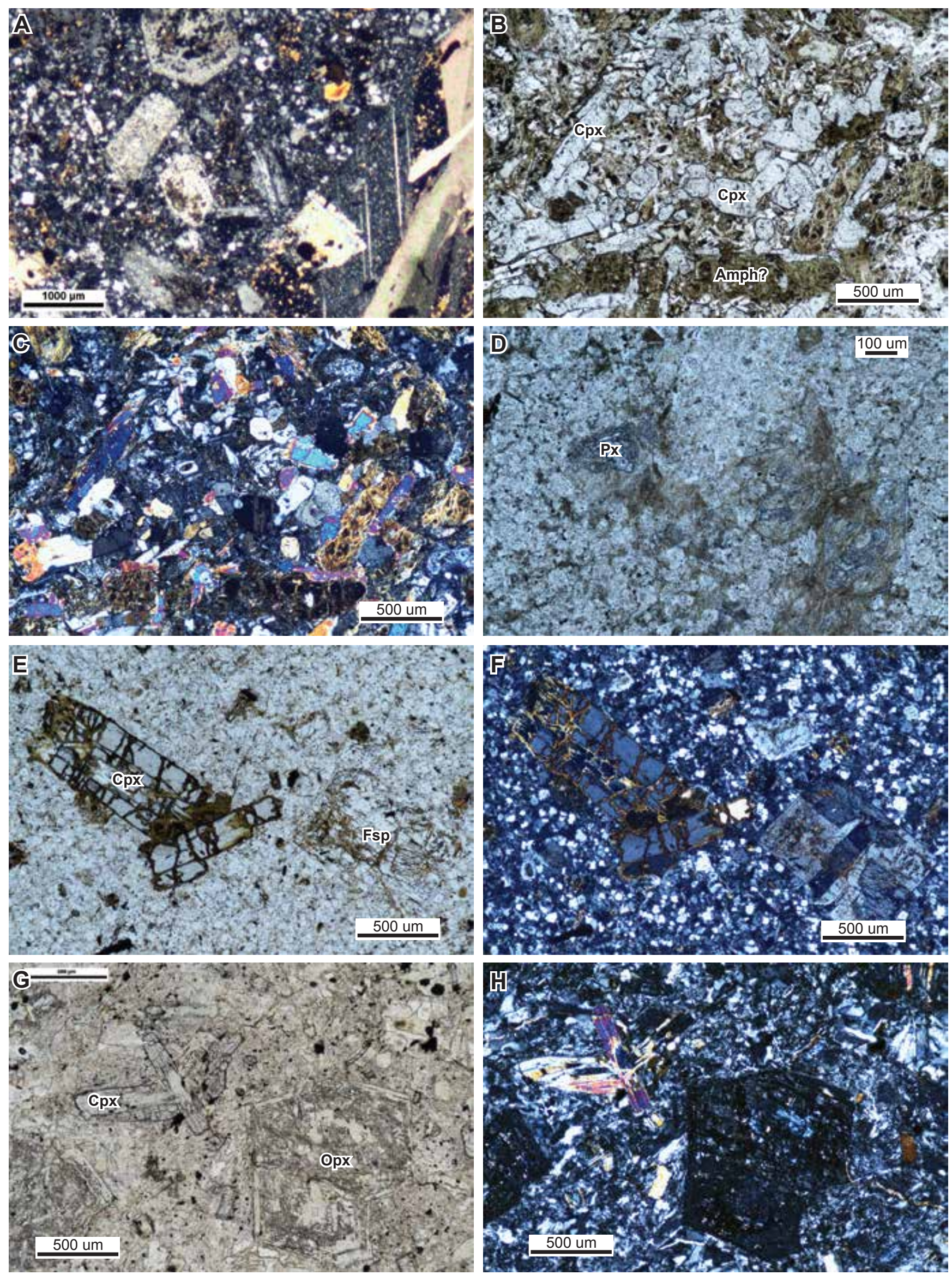

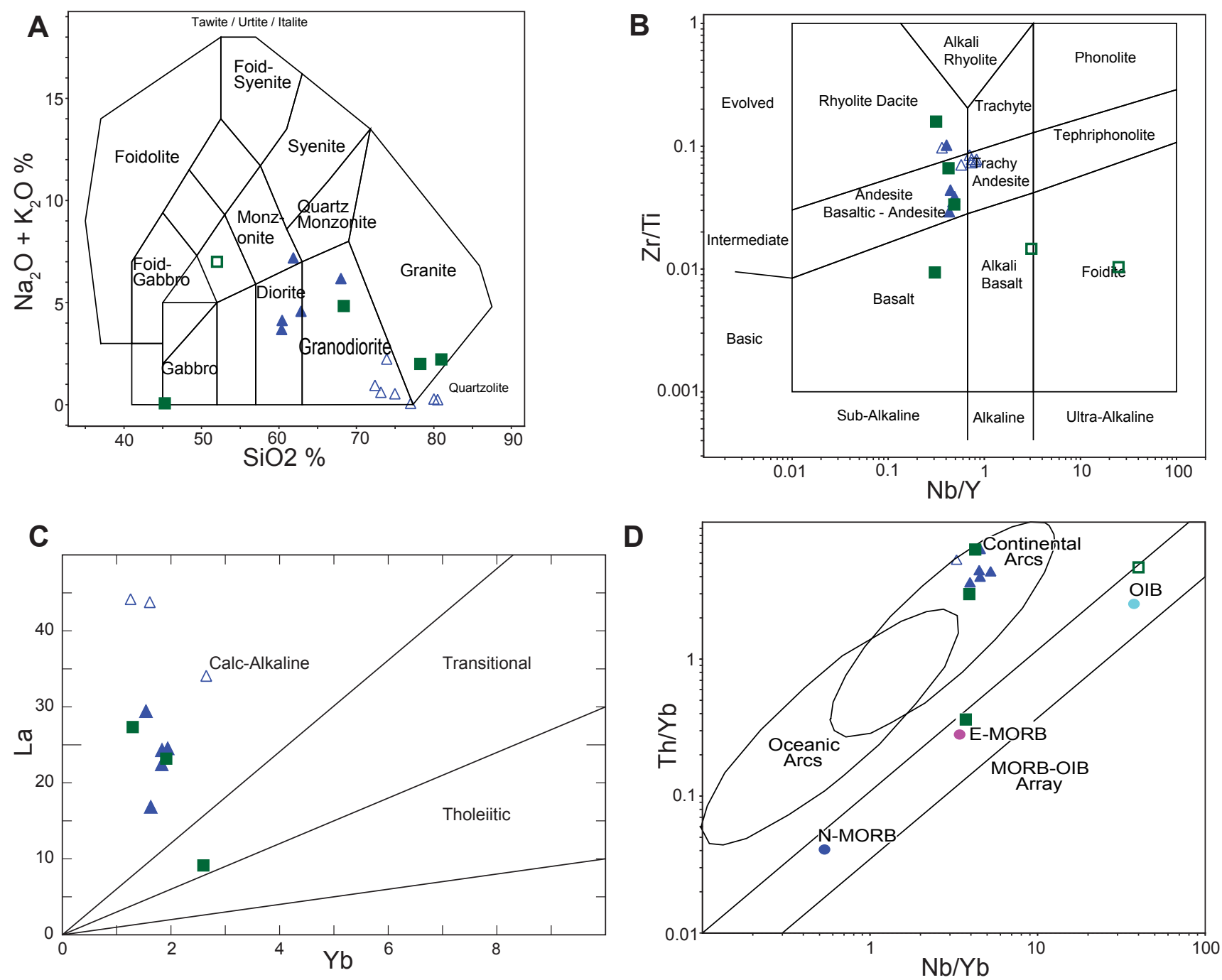
$\Delta \quad$ Earn Group tuff
․ Macmillan Pass
- Diorite
- Marg 


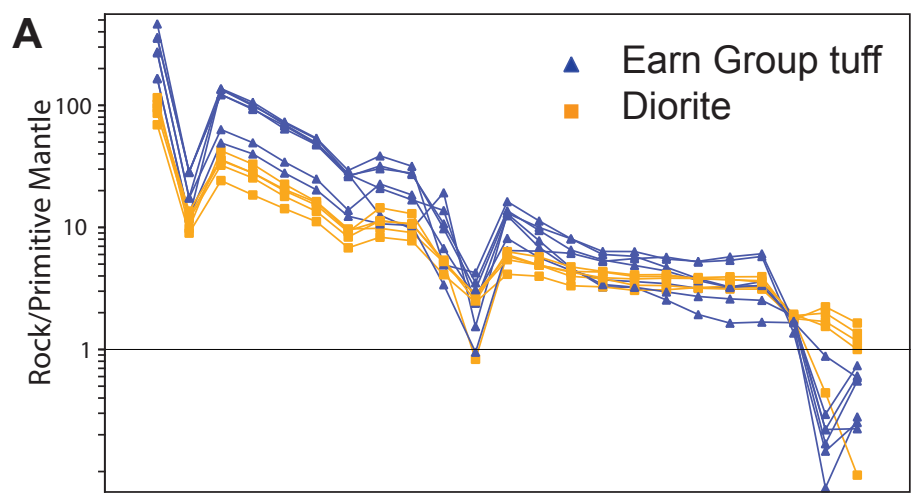

Th Nb La Ce Pr Nd Sm Zr Hf Eu Ti Gd Tb Dy Y Ho Er Tm Yb Lu Al Sc V

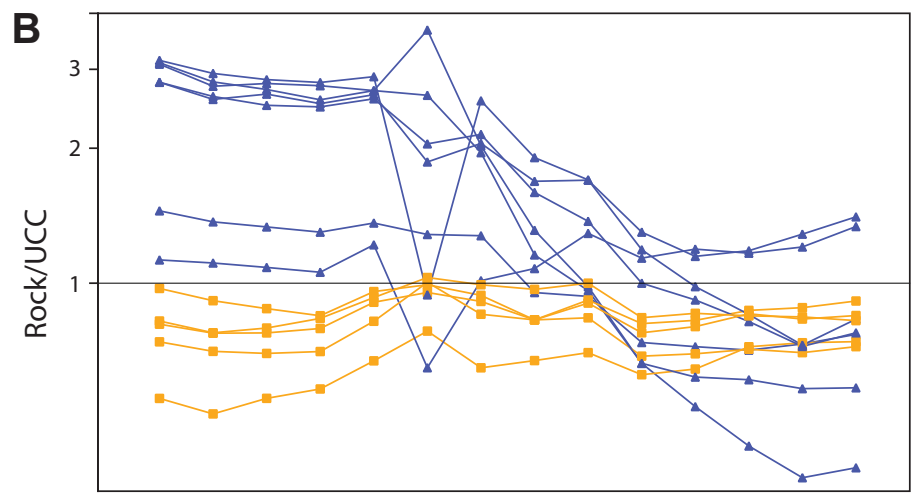

$\begin{array}{llllllllllllll}\mathrm{La} & \mathrm{Ce} & \mathrm{Pr} & \mathrm{Nd} & \mathrm{Sm} & \mathrm{Eu} & \mathrm{Gd} & \mathrm{Tb} & \mathrm{Dy} & \mathrm{Ho} & \mathrm{Er} & \mathrm{Tm} & \mathrm{Yb} & \mathrm{Lu}\end{array}$ 


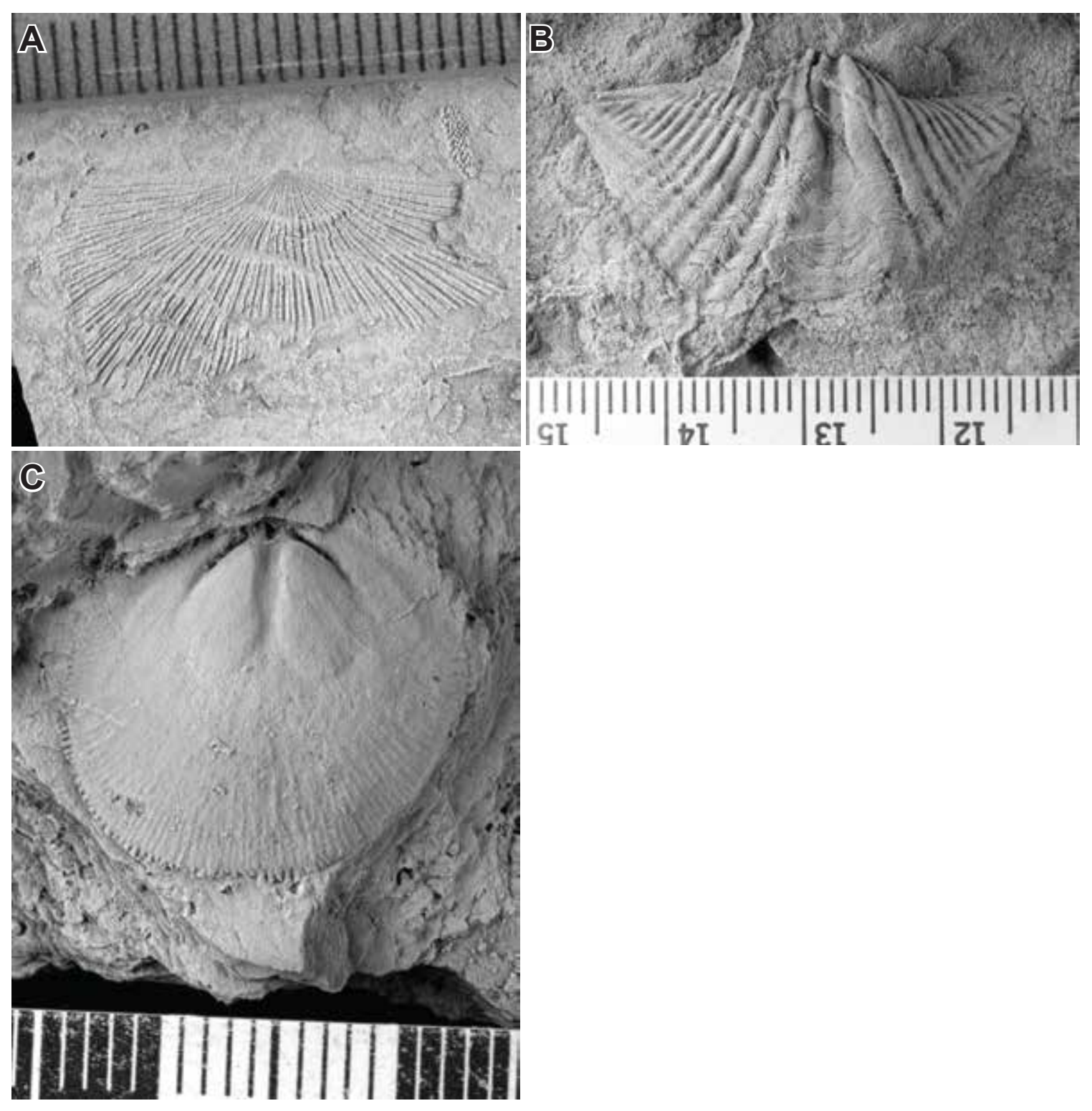




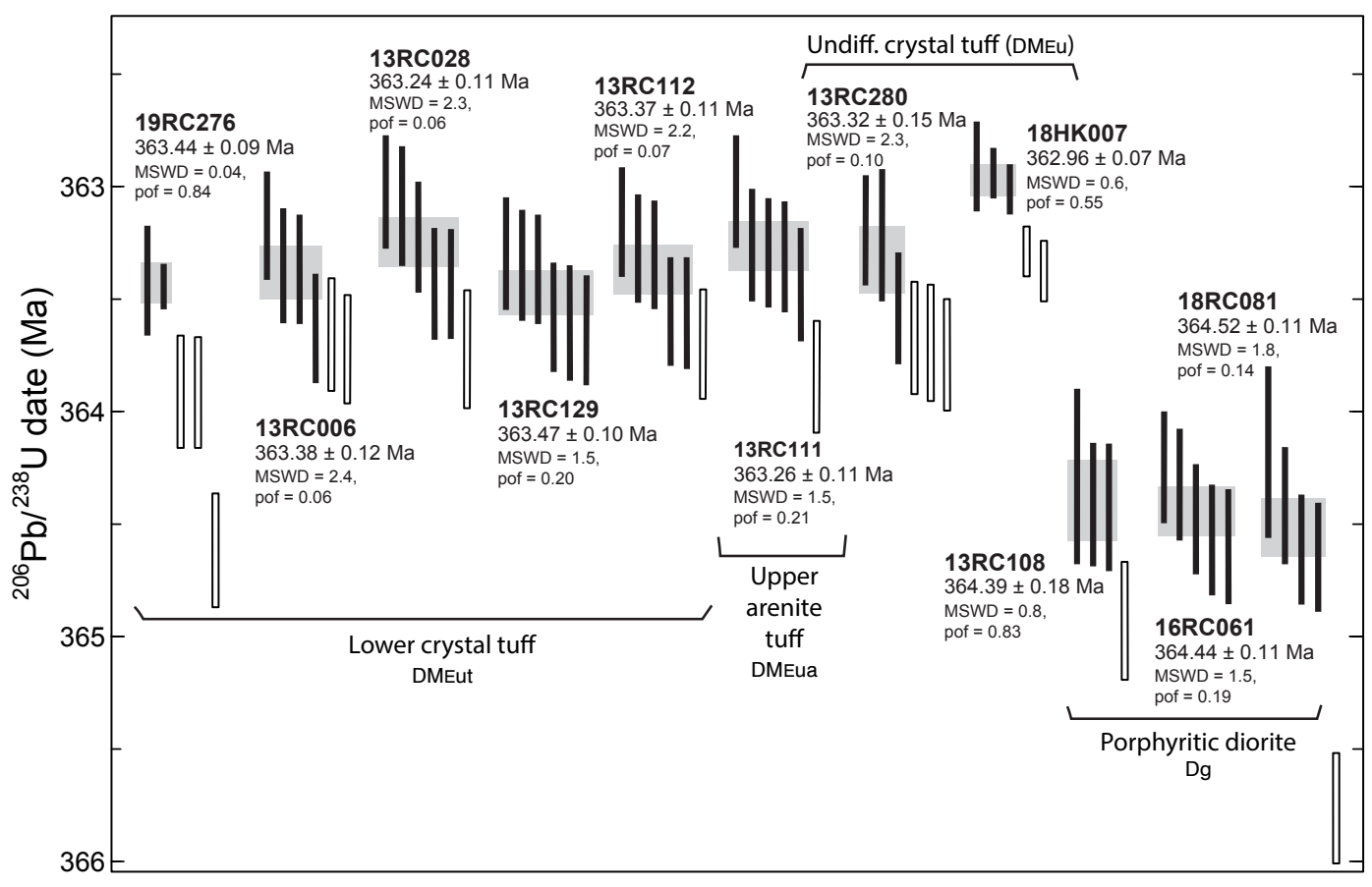

Fig. 14 


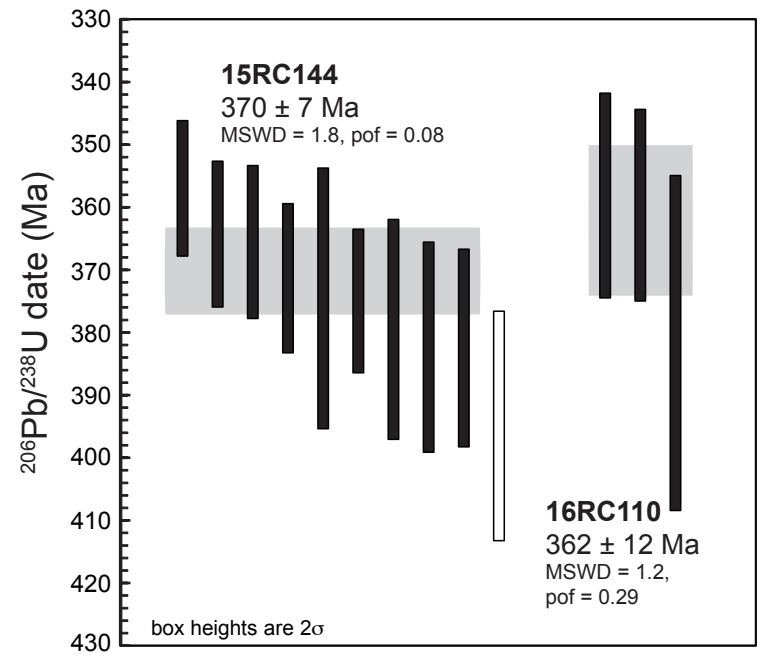

Fig. 15 


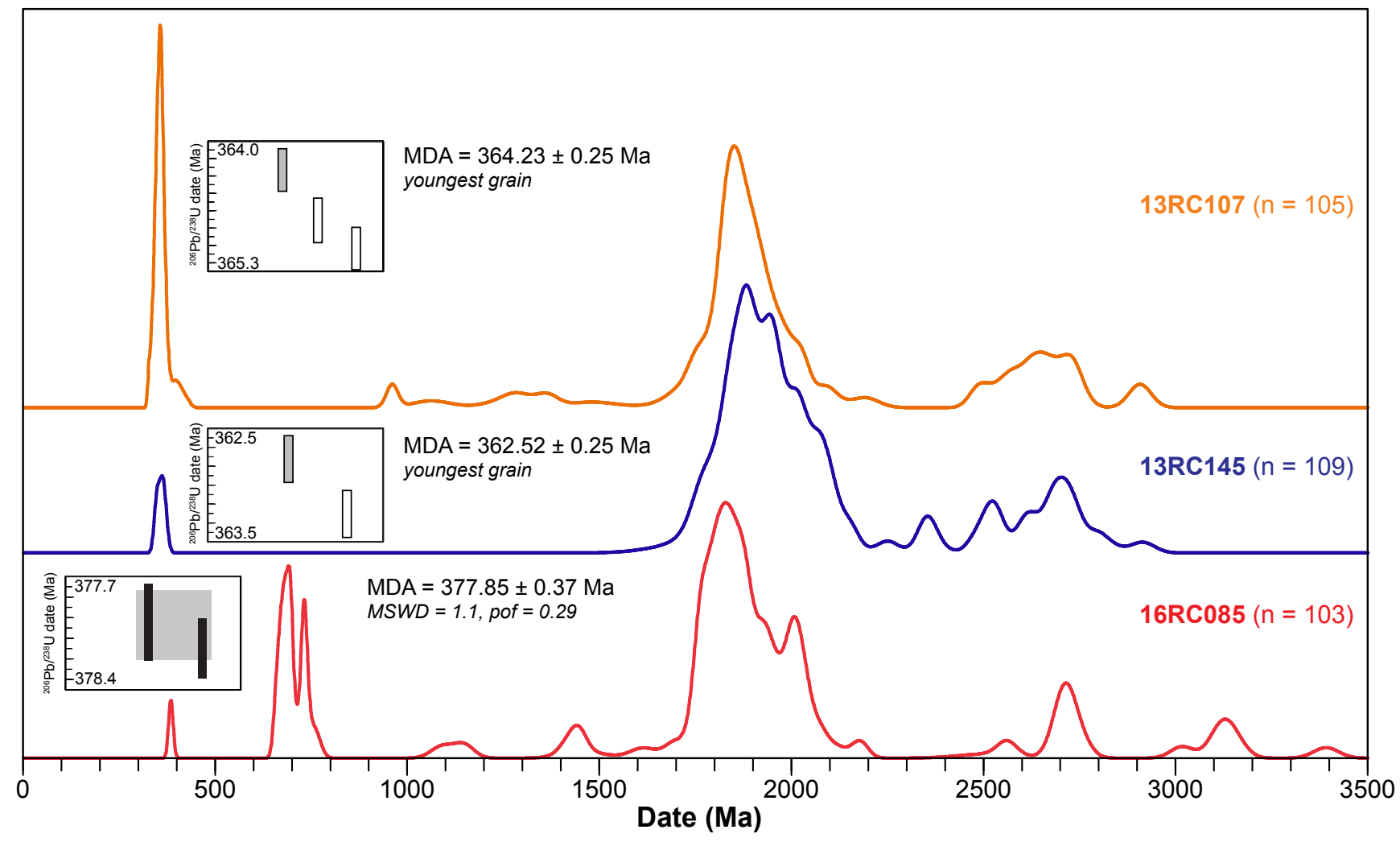

Fig. 16 


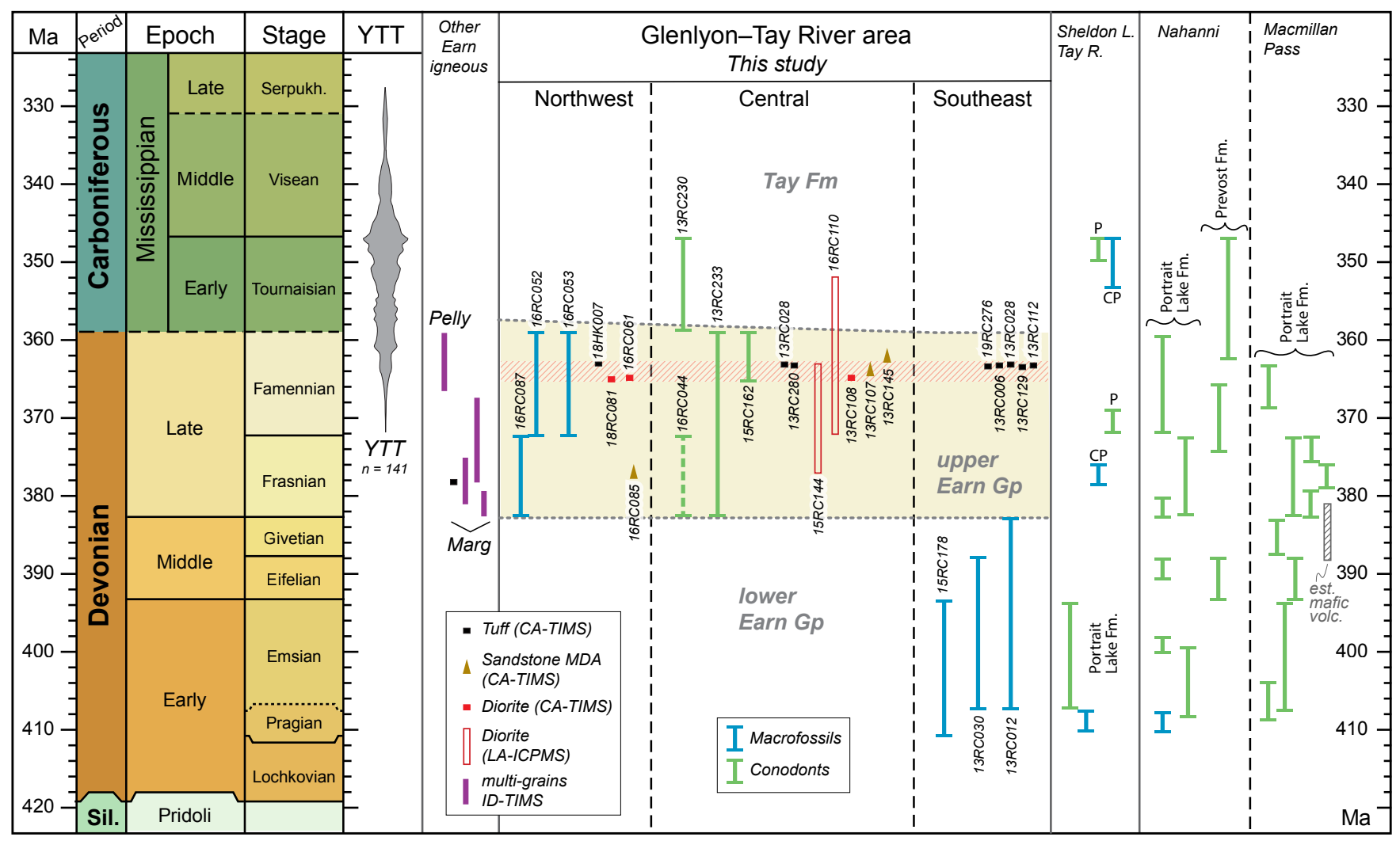

Fig. 17 